University of Rhode Island

DigitalCommons@URI

Open Access Dissertations

1970

\title{
Effect of Acute Hypoxia or Chronic Social Isolation on Brain Sensitivity and Barbiturate Metabolism
}

Irwin Paul Baumel

University of Rhode Island

Follow this and additional works at: https://digitalcommons.uri.edu/oa_diss

\section{Recommended Citation}

Baumel, Irwin Paul, "Effect of Acute Hypoxia or Chronic Social Isolation on Brain Sensitivity and Barbiturate Metabolism" (1970). Open Access Dissertations. Paper 140.

https://digitalcommons.uri.edu/oa_diss/140

This Dissertation is brought to you for free and open access by DigitalCommons@URI. It has been accepted for inclusion in Open Access Dissertations by an authorized administrator of DigitalCommons@URI. For more information, please contact digitalcommons-group@uri.edu. 
EFFECT OF ACUTE HYPOXIA OR CHRONIC SOCIAL ISOLATION ON BRAIN SENSITIVITY AND BARBITURATE METABOLISM BY

IRWIN PAUL BAUMEL

A THESIS SUBMITTED IN PARTIAL FULFILLMENT OF THE REQUIREMENTS FOR THE DEGREE OF DOCTOR OF PHILOSOPHY

IN

PHARMACOLOGY AND TOXICOLOGY

UNIVERSITY OF RHODE ISLAND

1970 
DOCTOR OF PHILOSOPHY THESIS

OF

IRWIN PAUL BAUNEL

Approved:

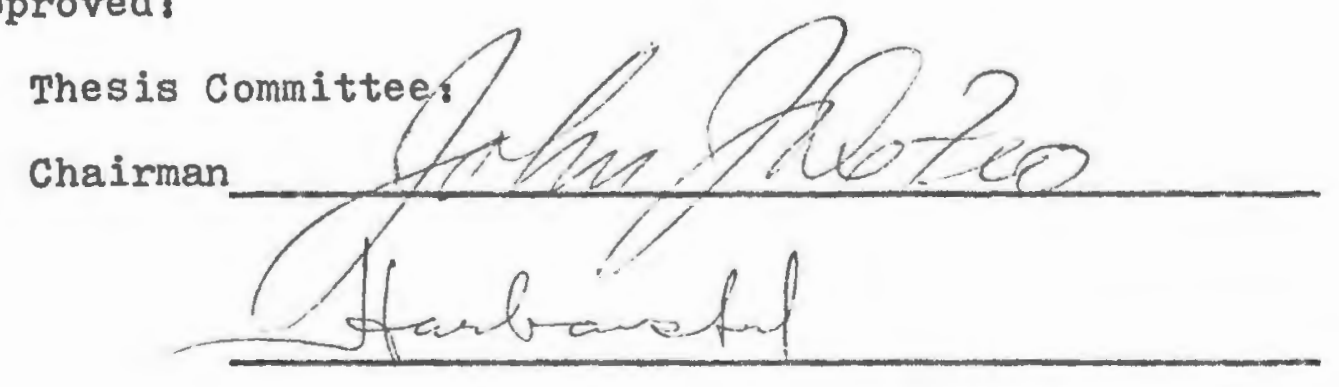

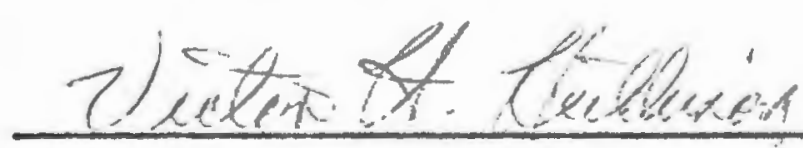

William R.Fenanto

Dean of the Graduate School

UNIVERSITY OF RHODE ISLAND

1970 


\begin{abstract}
Baumel, Irwin Paul, Ph.D., University of Rhode Island, July, 1970. Effect of Acute Hypoxia or Chronic Social Isolation on Brain Sensitivity and Barbiturate Metabolism.

The mechanisms by which hypoxia or social isolation interact with drug action were investigated by the use of several parameters including drug-induced narcosis, convilsions, change in body temperature and various biochemical parameters.
\end{abstract}

\title{
Acute Hypoxia
}

Hypobaric hypoxia $\left(304 \mathrm{~mm} \mathrm{Hg}, 10 \% \mathrm{O}_{2}\right)$ enhanced the depressant effects of barbital, pentobarbital and chloral hydrate in mice and rats. Mice were far more sensitive than rats, barbital narcosis being affected to the greatest extent. Reduced oxygen (10\%) at normal pressure also potentiated pentobarbital narcosis.

Hypothermia during hypoxia was greater in mice than in rats. Mice exposed to hypoxia at $30^{\circ} \mathrm{C}$ instead of $22^{\circ} \mathrm{C}$ ambient temperature did not exhibit hypothermia. Hypoxia at $22^{\circ} \mathrm{C}$ enhanced and prolonged the hypothermia induced by barbiturates and chloral hydrate. At $30^{\circ} \mathrm{C}$ hypoxia showed considerably less potentiation of barbital narcosis and hypothermia than at $22^{\circ} \mathrm{C}$. These parameters were moderately reduced with chloral hydrate and unaffected with respect to pentobarbital. 
Convulsions produced by intraperitoneal semicarbazide, m-fluorotyrosine or methionine sulphoximine were slgnifivantly reduced in mice exposed to hypoxia. Seizures due to intracerebral semicarbazide were also antagonized by hypoxia.

Hypoxic mice showed lower body concentration of pentobarbital on awakening and reduced rate of pentobarbital disappearance from the body than animals breathing room atmosphere.

Administration of sodium nitrite to mice markedly potentiated barbiturate narcosis. The hypothermia and methemoglobinemia produced by nitrite showed a temporal relationship to the potentiation of hexobarbital narcosis. Both reduction in body temperature and enhancement of barbital narcosis after sodium nitrite were prevented at $30^{\circ} \mathrm{C}$ ambient temperature, but potentiation of hexobarbital narcosis was unaffected.

Disappearance of hexobarbital from the whole-body of nitrite-treated mice was slower and barbiturate concentration at awakening was lower in these animals as compared to control mice.

Sodium nitrite did not inhibit hexobarbital metabolism in vitro or affect hexobarbital narcosis when injected intracerebrally.

Methylene blue effectively reduced nitrite-induced methemoglobinemia, but markedly potentiated barbiturate narcosis in the absence of nitrite.

Seizures produced by intracerebral semtcarbazide were antagonized by sodium nitrite injection. 
Brain and plasma levels of intraperitoneal barbital $\mathrm{C}^{14}$ were reduced after exposure to hypobaric hypoxia or injection of sodium nitrite when the labelled compound was given with a depressant dose $(300 \mathrm{mg} / \mathrm{kg})$ of unlabelled barbital. Excretion of barbital $\mathrm{C}^{14}$, as measured by brain and plasma levels oh after intraperitoneal injection, was slower in mice subjected to barbiturate narcosis during hypobaric hypoxia. Exposure to hypoxia or injection of sodium nitrite did not affect penetration of intravenously administered barbital $\mathrm{c}^{14}$ into brain.

These data suggest that hypoxia due to low ambient oxygen or injection of sodium nitrite decreases absorption, metabolism and excretion of barbiturates and lowers the threshold of brain neurons to drug-induced depression.

\section{Social Isolation}

Narcosis due to hexobarbital, pentobarbital, chloral hydrate or barbital was markedly reduced in male mice after 5 weeks of social deprivation. Socially deprived female mice also showed a decreased response to hexobarbital narcosis. However, only isolated males developed aggressiveness.

The metabolism of hexobarbital both in vivo and in vitro was enhanced in isolated animals. Mice deprived of social interactions gained righting reflex at a higher body level of hexobarbital as compared to the undeprived animals.

Development of aggressiveness in isolated male mice 
did not correlate temporally with the reduced response to hexobarbital.

Gonadectomy, but not adrenalectomy effectively prevented reduction of barbiturate potency and development of aggressiveness in socially deprived male mice.

Latency to avoidance of paw shock was significantly lower in socially deprived male mice. In addition, the decrement in avoidance produced by chlorpromazine in grouped mice was less pronounced in the deprived animals. These data show that chronic deprivation of social stimuli in mice increased the drug metabolizing activity of hepatic microsomes and raised arousal levels such that CNS susceptibility to drugs and physical stimuli was altered. In addition, the anabolic steroids appear to be involved in this response. These observations further suggest that alterations in barbiturate sensitivity and development of aggressiveness after social deprivation may have a different biological basis. 


\section{ACKNOWLEDGEMENTS}

The author wishes to express his gratitude to his wife, Susan, for her patience, understanding and thoughtfulness.

The author conveys his sincere appreciation to Drs. John J. DeFeo and Harbans Lal for their invaluable guidance throughout the duration of this study.

The author wishes to thank Messr. Arthur B. Pitterman for assistance in certain phases of this investigation.

The author also wishes to convey his thanks to the faculty and his fellow students in the department of pharmacology for their many helpful suggestions during these studies.

Financial support for this investigation was provided by NIMH Grant No. 1 RO3 HH 17603-01 and PHS Training Grant No. 1 TO1ES 00104 from the Division of Environmental Health Sciences through the Institute of Environmental Biology at the University of Rhode Island. 
TABIE OF CONTENTS

ABSTRACT $\ldots \ldots \ldots \ldots \ldots \ldots \ldots \ldots \ldots \ldots \ldots \ldots \ldots \ldots \ldots \ldots \ldots$

ACKNOWLEDGEMENTS.

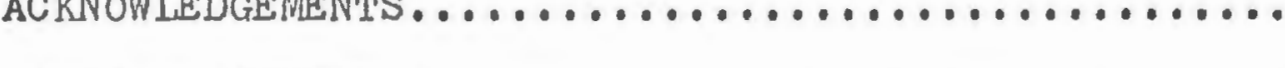

TABLE OF CONTENTS......................

LIST OF TABIES ........................

IIST OF FIGURES........................

INTRODUCTION...........................

LITERATURE SURVEY......................

Acute Hypoxia....................... Hypoxia Due to Methemoglobin........... Effects in Man..................... Effects in Animals.................... Effect of Hypoxia on Drug Activity........

Social Isolation..................... Effects in Man..................... Effects in Animals................... Effect of Social Isolation on

Drug Activity....................

EXPERIMENTAL. ..........................

Animals...........................

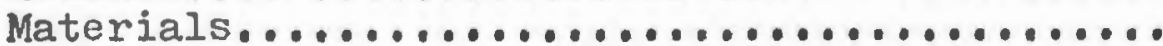

Hypobaric Chambers.....................

Exposure to Hypoxia.....................

Measurement of Drug-Induced Narcosis..........

Measurement of Body Temperature During Hypoxia

Measurement of Drug-Induced Hypothermia During

Measurement of Drug-Induced Convulsions During

Hypoxia...........................

Injection of Drugs into Brain.............

Social Deprivation....................

Aggressive Behavior....................

Surgical Procedures.................... Conditioning of Avoidance Behavior........... Measurement of Avoidance Behavior........... Statistical Methods.................... Determination of thole-Body Levels of

Barbiturates........................ Preparation of $9,000 \times \mathrm{G}$ Supeinatants........ Determination of In Vitro Metabolism of

Hexobarbital...................... 
Determination of Methemoglobin Levels in Blood

Determination of Brain and Plasma Levels of

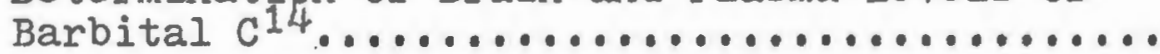

RESULTS..............................

Effect of Hypoxia on Drug-Induced Narcosis.... Effect of Hypoxia on Body Temperature......... Effect of Hypoxia and Ambient Temperature on Drug-Induced Hypothermia and Narcosis......... Effect of Hypoxia on Drug-Induced Convulsions. Effect of Hypobaric Hypoxia on Disappearance of Body Pentobarbital and Pentobarbital

Concentration at Awakening.............. Effect of Sodium Nitrite on Blood Methemoglobin, Body Temperature and Barbiturate Narcosis............................ Effect of Sodium Nitrite on Disappearance of Body Hexobarbital and Hexobarbital Concentration at Awakening................... Effect of Intracerebral Sodium Nitrite on Body Temperature and Hexobarbital Narcosis.... Effect of Sodium Nitrite on Hexobarbital

Oxidase Activity....................... Effect of Miethylene Blue on Nitrite-Induced Methemoglobinemia and Enhancement of Hexobarbital Narcosis........................ Effect of Hypobaric Hypoxia and Sodium Nitrite on Brain and Plasma Levels of Barbital c14.... Effect of Social Deprivation on Drug-Induced Narcosis............................. Effect of Social Deprivation on Hexobarbital Oxidase Activity...................... Effect of Social Deprivation on Disappearance of Body Hexobarbital and Hexobarbital Concentration at Awakening................... Relationship of Pharmacological Alterations to Isolation-Induced $\Lambda$ ggression............ Effect of liodified Endocrine Function on Isolation-Induced Pharmacologic Alterations and Aggression....................... Effect of Social Deprivation on Shock

Avoidance Behavior....................

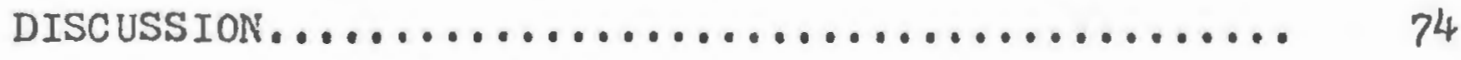

SUMIIARY AND CONCLUSIONS..................... 85

REFERENCES................................. 89

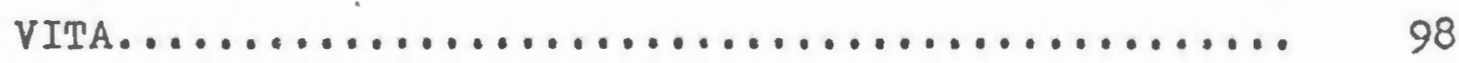


LIST OF TABLES

Table

Page

1 Effect of Hypobaric Exposure on DrugInduced Narcosis..................

2 Effect of Hypoxia on Duration of Pentobarbital Narcosis..................

3 Effect of Hypobaric Hypoxia on DrugInduced Narcosis at Two Ambient Tempera-

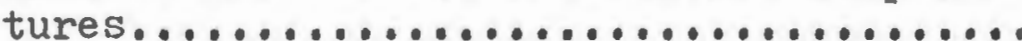

4 Effect of Hypobaric Hypoxia on Disappearance of Body Pentobarbital and Pentobarbital Concentration at Awakening........

5 Effect of Sodium Nitrite on Body Temperature and Barbiturate Narcosis at Two Ambient Temperatures..................

6 Effect of Sodium Nitrite on Disappearance of Body Hexobarbital and Hexobarbital

Concentration at Awakening...........

7 Effect of Intracerebral Sodium Nitrite on Body Temperature and Hexobarbital Narcosis............................

8 Effect of Sodium Nitrite on the Metabolism of Hexobarbital by Mouse Liver 9,000 x G Supernatant..................

9 Effect of Methylene Blue on NitriteInduced Methemoglobinemia...........

10 Effect of Methylene Blue on NitriteInduced Potentiation of Hexobarbital Narcosis.........................

11 Onset and Duration of Barbital Narcosis in Mice Treated with Methylene Blue......

12 Effect of Hypobaric Hypoxia and Sodium Nitrite on the Induction of Barbital Narcosis.........................

13A Effect of Sodium Nitrite and Barbital on Brain and Plasma Levels of Barbital $\mathrm{C}^{14}$. 
List of Tables (continued)

Table

Page

13B Effect of Sodium Nitrite or Hypobaric Hypoxia on Brain and Plasma Levels of

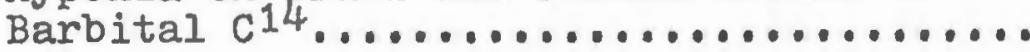

13C Effect of Hypobaric Hypoxia and Barbital on Brain and Plasma Levels of Barbital c14 6 Hours after Injection............

14 Effect of Sodium Nitrite or Hypobaric Hypoxia on the Penetration of Intravenous Barbital $\mathrm{C}^{14}$ into Brain................

15 Effect of Prolonged Social Isolation on Drug-Induced Narcos is in Mice...........

16 Onset of Barbital Narcosis in Chronically Isolated and Grouped Mice.............

17 Effect of Social Isolation on Body Weight and Hexobarbital oxidase Activity in Mice

18 Effect of Social Isolation on Hexobarbital Metabolism and Hexobarbital Concentration at Awakening................

19 Effect of Endocrine Modification on Isolation-Induced Aggression and Decrease in Hexobarbital Narcosis................

20 Effect of Chlorpromazine on Conditioned Avoidance Behavior in Grouped and Isolated Mice.......................... 
LIST OF FIGURES

Figure

Page

1 Hypobaric Chamber System..............

2 Rectal Temperature of Mice and Rats Exposed to the Hypobaric Environment.....

3 Effect of Ambient Temperature on the Hypothermia During Hypoxia in Mice.......

4 Effect of Hypoxia and Ambient Temperature on Pentobarbital-Induced Hypothermia in Mice..........................

5 Effect of Hypoxia and Ambient Temperature on Chloral Hydrate-Induced Hypothermia in Mice...........................

6 Effect of Hypoxia and Ambient Temperature on Barbital-Induced Hypothermia in Mice..

7 Effect of Hypobaric Hypoxia on Semicarbazide Convulsions in Mice..............

8 Effect of Hypobaric Hypoxia on m-Fluorotyrosine Convulsions and Lethality.......

9 Effect of Hypobaric Hypoxia on Methionine Sulphoximine Convulsions in Mice........

10 Effect of Hypobaric Hypoxia and Sodium Nitrite on Convulsions Following Intracerebral Injection of Semicarbazide......

11 Time Course of Effect of Sodium Nitrite on Hexobarbital Narcosis, Body Temperature and Blood Methemoglobin...........

12 Fighting Response and Hexobarbital Narco$\mathrm{sis}$ in Mice Subjected to Social Deprivation..........................

13 Median Latency to Avoidance of Electric Shock in Isolated and Grouped Mice....... 


\section{INTRODUCTION}

Numerous factors in the environment have been known to affect physiological processes within the organism resulting in altered pharmacologic effects. Factors such as ambient temperature (Chance, 1947, 1957), pressure (Bernardini, 1969), population density (Chance, 1947; Chance and Mackintosh, 1962) and seasonal variations (Heller et al.. 1957) may influence the onset, potency or duration of action of a compound thus altering the resultant pharmacodynamic activity.

Current interest in drug therapy during space and undersea exploration has stimulated research into factors which may affect drug activity in a controlled environment. Variations in the gaseous environment of the space cabin or undersea laboratory and the social factors involved in prolonged missions may well affect the physiological and biochemical processes within the organism which could produce possible changes in drug activity. A better understanding of mechanisms underlying these changes may aid in the development of preventative methods to counteract undesirable effects induced by environmental extremes. Consequently. the present investigation was undertaken to explore mechanisms assoclated with changes in pharmacologic response induced by acute hypoxia and prolonged sosial isolation. Initial studies involved testing the pharmacological sensitivity of animals subjected to hypoxia or social 
isolation to selected central nervous system (CNS) depressants. Barbital, which is excreted unmetabolized (Dorfman and Goldbaum, 1947; Maynert and Van Dyke, 1950; Ebert et al., 1964) was chosen as an indicator for alteration of CNS sensitivity or the rate of drug entry into brain. Duration of narcosis due to hexobarbital or pentobarbital which is limited by the rate of their metabolism in hepatic microsomes (Cooper and Brodie, 1955, 1957) and chloral hydrate which is metabolized by soluble hepatic alcohol-dehydrogenase (Friedman and Cooper, 1960), were employed to test drug metabolizing enzymes. In addition, several convulsant agents which interact with specific pathways of brain metabolism were employed to further evaluate changes in brain sensitivity. Specific biochemical studies were then performed to verify biological alterations suggested by these experiments.

Since drug-induced CNS depression is sensitive to body temperature (Fuhrman, 1947, Setnikar and Temelcou, 1962) and hypoxia induces hypothermia (Gellhorn, 1937) concurrent measurement of rectal temperature was included in this study. Methemoglobinemia produced by nitrites is a form of tissue hypoxia (Darling and Roughton, 1942). Consequently the effect of sodium nitrite injection on brain sensitivity and barbiturate metabolism was compared with that of hypobaric hypoxia. 


\section{IITERATURE SURVEY}

\section{Acute Hypoxia}

The term "hypoxia" means decreased availability of' oxygen to the cells of the body. This condition may be caused by pulmonary disease (Oswald and Fry, 1962), circulatory insufficiency (Finley et al., 1962), anemias and tissue edema (Van Liere and Stickney, 1963). A common form of hypoxia encountered by aviators, astronauts and others working at high altitudes or in controlled gaseous environments is inadequate oxygenation of the lungs due to a deficiency of oxygen in the atmosphere.

Hypoxia Due to Reduced Barometric Pressure

The total pressure of all gases in the air (barometric pressure) decreases as one ascends to higher altitudes. At sea level or normal room atmosphere, barometric pressure averages $760 \mathrm{~mm} \mathrm{Hg}$ and the pressure contributed by oxygen to the total pressure (partial pressure, $\mathrm{pO}_{2}$ ) is $159 \mathrm{~mm} \mathrm{Hg}$. Since oxygen remains at slightly less than $21 \%$ of the total gaseous atmosphere, the $\mathrm{pO}_{2}$ will decrease with corresponding decreases in total barometric pressure. Thus at 10,000 ft. barometric pressure $=523 \mathrm{~mm} \mathrm{Hg}$ and $\mathrm{pO}_{2}=110 \mathrm{~mm} \mathrm{Hg}$, whereas at $19.000 \mathrm{ft}$. the barometric pressure is $364 \mathrm{~mm} \mathrm{Hg}$ and $\mathrm{pO}_{2}=76$ $\mathrm{mm} \mathrm{Hg} \mathrm{equivalent} \mathrm{to} \mathrm{a} 10 \%$ oxygen atmosphere at sea level $(760 \mathrm{~mm} \mathrm{Hg})$.

Up to an elevation of approximately $10,000 \mathrm{ft}$. the 
$\mathrm{pO}_{2}$ in the air is sufficient to maintain arterial oxygen saturation at about $90 \%$. However, above $10,000 \mathrm{ft}$. elevation, arterial oxygen saturation falls progressively to approximately $70 \%$ at $19,000 \mathrm{ft}$. and still lower at higher altitudes, severely reducing the supply of oxygen delivered by blood to the tissues (Folk, 1966).

Hypoxia Due to liethemoglobin

The oxidized, ferric form of hemoglobin is a chocolate-colored pigment called methemoglobin. A great many substances such as nitrites, chlorates, phenacetin, acetanilid, sulfanilamide, nitrobenzene, quinones and analine can produce methemoglobin (Bodansky, 1951). This group includes drugs used therapeutically as well as chemicals commonly used as purifiers or preservatives in food and drinking water. Thus methemoglobinemia may be produced in various situations encountered in everyday life.

Methemoglobin will not carry oxygen. When one or more of the four iron atoms in a molecule of hemoglobin is oxidized to the ferric state, the affinity of oxygen for the other sites is increased. The oxyhemoglobin dissociation curve is shifted to the left, so the delivery of oxygen to the tissues is impaired (Darling and Roughton, 1942).

Erythrocytes normally contain a small steady-state level of methemoglobin, regulated by two enzyme systems that reduce methemoglobin back to hemoglobin; these are methemoglobin diaphorase (diaphorase I, NADH dependent) and methemoglobin reductase (diaphorase II) using NADPH as coenzyme 
(Jaffe, 1964). Methylene blue accelerates reduction of methemoglobin to hemoglobin by acting as electron acceptor between NADPH and methemoglobin thus accelerating methemoglobin reductase activity (Huennekens et al., 1957, Sass et al., 1967).

\section{Effects in Man}

The variety and severity of symptoms appearing on acute exposure to hypoxic conditions are dependent upon the degree and length of exposure to hypoxia.

The earliest effect of hypoxia is decreased proficiency of night vision. Light normally needed to see dimly illuminated surroundings must be increased progressively at altitudes of $8,000 \mathrm{ft}$. and above. At 17,000 ft. visual acuity is reduced to $50 \%$ of the sea level value (McFarland and Halperin, 1940).

Pulmonary ventilation increases at altitudes

above $8,000 \mathrm{ft}$. to a maximum of $65 \%$ above normal at 20,000 ft. resulting in a respiratory alkalosis due to exhalation of excess carbon dioxide (Guyton, 1969).

Beginning at approximately 12,000 ft. and increasing in severity with higher altitudes, one may experience drowsiness, fatigue, possibly headache and sometimes euphoria (Armstrong, 1961; Brown, 1963). Convulsions and coma may occur at about 23,000 ft. (Schade and McMenemey, 1963; Schaeffer, 1962).

Significant decreases in mental proficiency for judgement and impairment of memory processes have been 
noted by McFarland (1938) and Malmo and Finnan (1944). Decrements in performance of a reasoning task, pairedword association and memory for pattern and position as measured by immediate and delayed recall were noted at altitudes of 8-10,000 ft. with increasing effects at higher altitudes.

Reduction in body temperature of approximately $1^{\circ} \mathrm{C}$ has been noted in man exposed to $10 \%$ oxygen at room temperature (Kottke et al.. 1948).

Effects in Animals

Impairment of visual acuity in rats using discrimination of upright and inverted figures was suggested in experiments by Shock and Scow (1942). Rats acutely exposed to $10 \%$ oxygen showed increased errors in the discrimination task.

Effects on memory and learning during hypoxia have been noted by several workers. In rats exposed to $30,000 \mathrm{ft}$. (226 mm Hg, $\mathrm{pO}_{2}=47 \mathrm{~mm} \mathrm{Hg}$ ) for varying periods of time, Hurder (1951) observed decreases in acquisition of maze performance 6-7 weeks after exposure to the hypoxic atmosphere, the decrement being proportional to the time of exposure to hypoxia. Thompson (195?) observed that exposure of rats to $20,000 \mathrm{ft}$. for 10 minutes decreased retention of horizontalvertical discrimination $2 \mathrm{~min}$, but not 1.5 and $4 \mathrm{~h}$ after hypoxic exposure. In addition, exposure to $30,000 \mathrm{ft} .\left(6 \% \mathrm{O}_{2}\right)$ enhanced the retrograde amnesia in rats produced by electroconvulsive shock. Ledwith (1967) observed that subjecting 
rats to $9 \%$ oxygen delayed acquisition of a shuttle avoidance task. Concentrations of oxygen above $9 \%$ were essentially ineffective. Weinstein (1966), working with mice trained to escape from carbon dioxide, noted that severe hypoxia (6\% oxygen or less) increased the time taken to escape, whereas mild hypoxia $\left(10 \% \mathrm{O}_{2}\right)$ is associated with quicker times than normal room air $\left(21 \% \mathrm{O}_{2}\right)$. Mice exposed to hypoxia become extensively poikilothermic and show large reductions in body temperature (Gellhorn, 1937). Hypothermia is also present in hypoxic rats and dogs but to considerably less degree (Kottke e.t al. . 1948).

Effect of Hypoxia on Drug Activity

Early studies by Moore (1935) showed that strychnine was more toxic to rats and ground squirrels at higher altitudes. In addition, Lehman and Hanzlick (1932) found that digitalis was more toxic to cats and pigeons subjected to a reduced oxygen atmosphere. Tainter (1934) also noted that dinitrophenol produced a greater incidence of ;ethal effects in hypoxic animals. More recent studies indicated that mice acutely exposed to hypobaric hypoxia exhibited increased sensitivity to the lethal effects of amphetamine and reserpine (Baumel et al., 1967; Robinson et al., 1969). The decrease in motor activity produced by chlorpromazine and meprobamate in mice is potentiated on exposure to hypoxia (Sparvieri, 1960). Further, narcosis due to hexobarbital was prolonged in mice or rats acutely exposed to 
hypobaric hypoxia (Robinson et al., 1968; Mustala and Azarnoff, 1969).

The administration of sodium nitrite or related compounds to mice has been observed to markedly potentiate pentobarbital narcosis (Wooster and Sunderman, 1949).

\section{Social Isolation}

Depriving the organism of social interactions removes the normal stimuli obtained from group contacts resulting in changes in behavior and physiologic responses of the organism.

\section{Effects in Man}

The effects of restricted environments during human childhood have been investigated by Dennis and Dennis (1951). These researchers greatly reduced the normal amount of social interaction and the availability of manipulable objects (toys) in rearing twin girls until the age of 13 months. The children were found to be abnormally slow in developing some complex motor activities: sitting alone, standing with support, and visually directed reaching and grasping. These deficiencies were not due to muscular weakness or lack of exercise, since diffuse motor activity was almost continuous when the children were awake. In general, children who spent infancy in an institutionalized environment with poor social contacts have shown signs of low intelligence, abnormal passivity and dependency (Spitz, 1946; Goldfarb, 1955; Dennis, 1960). 
Prolonged social isolation of adults such as prisoners in solitary confinement or explorers alone in the Arctic have produced psychotic-like behaviors such as hallucinations, savior types of delusions, conversations with inanimate objects and paranoia (Lilly, 1956; Leiderman and Stern, 1961).

Physiologic changes in man during varying periods of isolation have included a slowing of EEG activity after 7 days of deprivation (Heron, 1961), decreased respiratory rate and blood pressure during 60 days of isolation (Agadzhanian et al.. 1963), decreased body weight after 4 days of deprivation (Myers et al., 1966) but little or no effect on production of adrenocortical or adrenomedullary hormones (Zubek and Schutte, 1966; Murphy et al., 1955).

The interaction of drugs with social deprivation in man has been investigated with respect to lysergic acid diethyl amide (ISD). Cohen and Edwards (1964), noted that men subjected to short-term deprivation were more resistant to the hallucinogenic and physiologic effects of ISD. Additional studies employed the hallucinogenic phencyclidine and found comparable results (Lawes, 1963).

\section{Effects in Animals}

Beach and Jaynes (1954) and Melzack (1963) have shown that birds, rats and dogs reared in isolation demonstrate inappropriate sexual behavior including immature sex play, failure to respond to the call of other members of the species, and inability to discriminate 
sexually relevant cues. Rearing animals in isolation also makes them less viable when stressed (King and Common, 1955). In addition, they are less gregarious than animals reared in communal cages (Beach and Jaynes, 1954) and are more disturbed and submissive in competitive situations (King and Gurmey, 1954). Prolonged social deprivation has also been observed to elicit intense aggression in male mice (Yen et al., 1959). These animals possess a heightened neuroexcitability which manifests itself in hypereactivity to physical stimuli (Kimbrell, 1967; King et al., 1955).

Physiologic alterations in isolated animals include a smaller adrenal weight (Christian, 1959; Valzelli and Garattini, 1968), higher plasma corticosterone Sigg, 1969, Guarino et al., 1967), decreased body weight (Hatch et al., 1965) and decreased turnover of brain serotonin (Giacalone et al., 1968).

Effect of Social Isolation on Drug Activity

Balazs et al (1962) noted that rats individually caged for 13 weeks showed an increased sensitivity to the cardiotoxic effects of isoproterenol. In addition, amphetamine is more toxic to mice chronically deprived of social interactions for a period of 4 weeks (Consolo et al., 1965a).

Reduced duration of pentobarbital narcosis was observed in rats caged individually from 6-14 weeks (Wiberg and Grice, 1965) and in mice deprived of social interac- 
tions for 4 weeks (Consolo et al., 1965b).

These observations suggest changes in brain sensitivity and drug metabolism in animals chronically deprived of social interactions. 


\section{EXPERIMENTAL}

\section{Animals}

Swiss albino, random bred male and female mice weighing 25-35 gm and Sprague-Dawley albino, random bred male rats (Charles River Farms, Wilmington, Mass,) weighing 150-250 gm were used. They were housed in animal quarters maintained at $21-23^{\circ} \mathrm{C}$ with room lights alternated on a $12 \mathrm{~h}$ light-dark cycle. Food and water were available ad libitum up to one hour before each experiment. Animals were used not earlier than one week after receipt from the supplier.

Materials

Analytical reagent grade chemicals or equivalent were used throughout this study. Co-factors (NADP and glucose-6-phosphate) were purchased from Calbiochem. The drugs used in this investigation were obtained from their respective manufacturers.

\section{Hypobaric Chambers}

The hypobaric chambers (Figure 1) utilized room air and consisted of four plexiglass desiccators (internal diameter 10", height 14". Ace Glass Inc.) connected in parallel via $\frac{2}{2} "$ rubber tubing to a vacuum pump (1/12 h.p., Gelman Instruments) through a manifold consisting of 1 " copper pipe. The degree and rate of reduction in ambient 


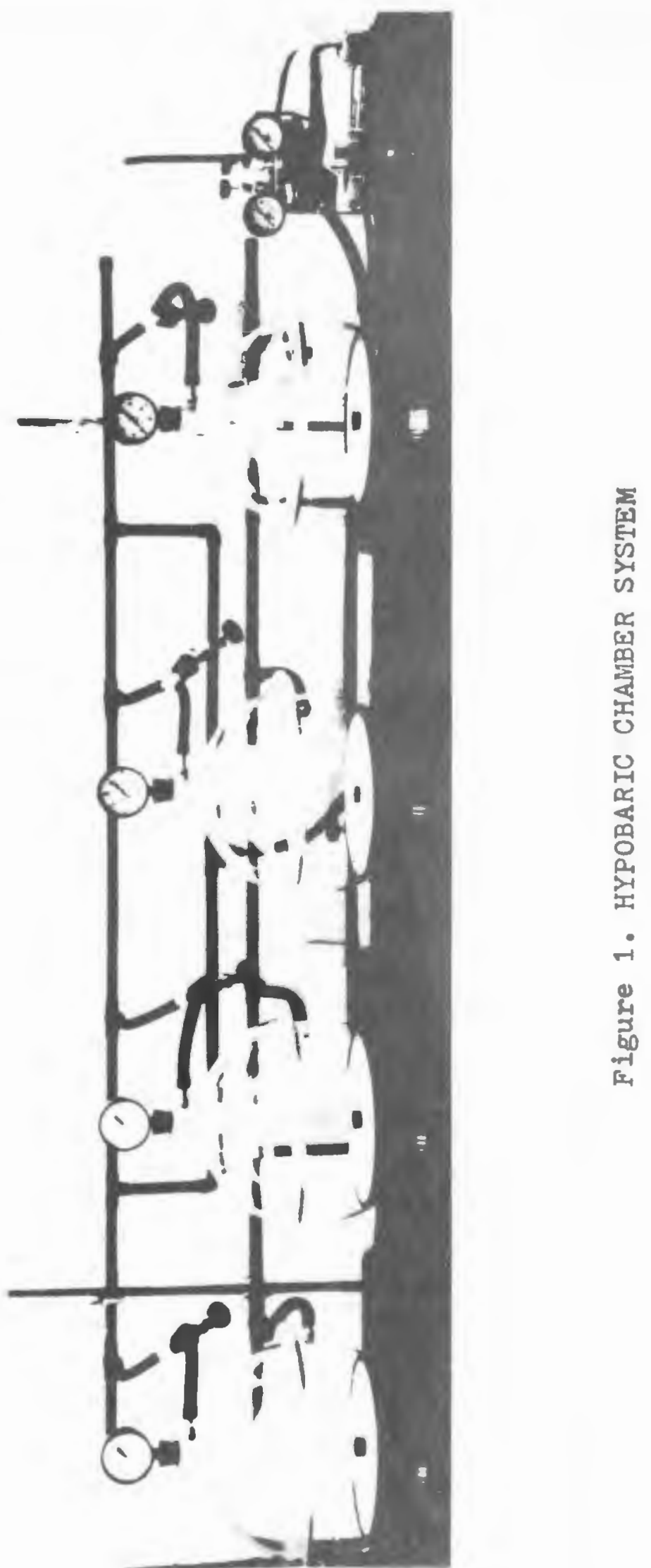


pressure within the chambers was controlled by a central needle valve attached to the air-intake manifold. The barometric pressure within the system was monitored by vacuum gauges on individual chambers and a mercury manometer attached to the end chamber. Seperate needle valves placed along the system permitted recompression of individual chambers independent of the other units. Decreasing barometric pressure within the chambers to $364 \mathrm{~mm} \mathrm{Hg}\left(10 \% 0_{2}\right)$ resulted in room air entering the system at approximately 9 liters/min which was assumed to be adequate for continuous removal of expired carbon dioxide and prevention of excess moisture condensation within the chambers. Under these conditions, the temperature within the chambers was maintained within $1^{0}$ of the ambient temperature.

Substitution of a low oxygen gas mixture for vacuum was accomplished by removal of the vacuum pump and attachment of a pressurized gas cylinder containing $10 \pm 1 \%$ oxygen in nitrogen to the air-intake manifold.

\section{Exposure to Hypoxia}

The animals were injected with drug while at room atmosphere $\left(760 \mathrm{~mm} \mathrm{Hg}, 21 \% \mathrm{O}_{2}\right)$ and immediately placed, in pairs, in each of the four chambers which were then decompressed in a $10 \mathrm{~min}$ period to $364 \mathrm{~mm} \mathrm{Hg}\left(10 \% \mathrm{O}_{2}\right)$. Controls were run concurrently in identical chambers open to room air. Animals were continually exposed to hypobaric hypoxia throughout the determination of drug effect. 
In the studies with reduced oxygen at normal

pressure the chambers were flushed continuously (10 liters $/ \mathrm{min}$ ) for $10 \mathrm{~min}$ after drug injection with a mixture of $10 \pm 1 \%$ oxygen in nitrogen and then flushed intermittently at 5 min intervals for the duration of the experiment.

Measurement of Drug-Induced Narcosis

Duration of narcosis throughout this study was taken as the interval between the loss and the gain of righting reflex, the endpoint of which was determined according to Wenzel and Lal (1959) using two rightings within $30 \mathrm{sec}$. The interval between injection of the drug and loss of righting reflex was designated as onset of narcosis. Since access to the mice was prevented during hypobaric hypoxia, loss to regain of righting reflex in these studies was determined by gently tilting the chambers to determine if the animals righted themselves and maintained balance by extension of the front paw outward on the chamber floor.

Measurement of Body Temperature During Hypoxia

Body temperature under hypobaric hypoxia was recorded at appropriate intervals by a rectal probe (Yellow Springs Instrument \#402) taped to the tail and connected by means of a rubber stopper inserted in the chamber wall to a telethermometer (Yellow Springs Instrument \#42SC) placed outside the chamber. For the temperature studies, in order to prevent damage to the thermistor probe, the 
animals were confined in plastic animal holders (Arthur H. Thomas Co.) placed inside the chambers. All measurements were made at $22^{\circ}$ or $30^{\circ} \mathrm{C}$ ambient temperature in a constant temperature environmental chamber. In experiments using the higher ambient temperature, animals were placed in the $30^{\circ}$ environment for $24 \mathrm{~h}$ prior to testing.

Measurement of Drug-Induced Hypothermia During Hypoxia

Mice were injected intraperitoneally with drug at room atmosphere and exposed to $364 \mathrm{~mm} \mathrm{Hg}$ as previously described. Afeter selected intervals of exposure to the hypobaric environment, mice were returned to room atmosphere, removed from the chambers and their rectal temperature measured. Restraint or rectal probes were not utilized in the chambers during hypoxia since it was desired to maintain normal loss and regain of righting reflex. Animals not losing righting reflex initially were excluded from the study.

Measurement of Drug-Induced Convulsions During Hypoxia

Mice were injected intraperitoneally with the convulsant drug while at room atmosphere and exposed, in pairs, in the hypobaric chambers to $364 \mathrm{~mm} \mathrm{Hg} \cdot\left(10 \% \mathrm{O}_{2}\right)$. Controls were run concurrently in identical chambers open to room air. Clonic or tonic convulsions were then recorded in individual mice during hypoxia.

Injection of Drugs into Brain

Mice were either exposed for $2 \mathrm{~h}$ to hypobaric hypoxia 
(364 $\mathrm{mm} \mathrm{Hg}, 10 \% \mathrm{O}_{2}$ ) or administered sodium nitrite (100 mg $/ \mathrm{kg}$ subcutaneously, $30 \mathrm{~min}$ pretreatment) and injected intracerebrally with semicarbazide (100 ug/mouse). In one experiment mice received sodium nitrite intracerebrally (50 ug/mouse).

The procedure of Haley and McCormick (1957) was used for direct injection of drugs into brain. Freshly prepared, aqueous drug solutions were administered intracerebrally in a volume of $0.01 \mathrm{ml} /$ mouse, the site of injection being a point $2 \mathrm{~mm}$ on either side of the midline joining the anterior bases of the ears. The injection was made with a 22 gauge needle attached to a Hamilton microliter syringe inserted perpendicularly through the skull into the brain. Penetration of the needle was limited to $1 / 8$ inch by polyethylene tubing placed above the needle point. Injection of a $0.5 \%$ aqueous solution of methylene blue verified localization of dye particles in the third and fourth ventricles thus ensuring adequate penetration of drug solution into the brain tissue via this technique.

Social Deprivation

Mice weighing 18-20 gm were housed either 1 to a cage or 10 to a cage in stainless steel cages $\left(9.5^{\prime \prime} \times 7^{\prime \prime}\right.$ x 7") with wire mesh on fronts and bottoms. Solid walls on the remaining 3 sides reduced visual or tactile contacts of the isolated mice with other animals. Animals were not handled or removed from their cages during the deprivation period but were kept clean by changing the bottom pans 
regularly. The mice were subject to all daily noises of the animal room. Ambient temperature was maintained at 21$23^{\circ} \mathrm{C}$ and room lights alternated on a $12 \mathrm{~h}$ light-dark cycle.

Determination of Aggressive Behavior

The presence or absence of aggressive behavior was determined by placing 5 pairs of isolated mice in strange cages for 15 minutes. Typical aggressive behavior consisted of tail rattling and rearing on hind paws assuming the fighting position which culminated in severe biting and scratching.

Surgical Procedures Prior to Social Deprivation Adrenalectomized male mice weighing 18-20 gm were obtained 1 week post-surgery from Charles River Farms and were housed in the animal quarters in a group of twenty for an additional week prior to 1solation. Gonadectomy in male mice was performed in this laboratory and consisted of removal of both testes and epididymis from a small incision made in the scrotal sac under light ether anesthesia. Wound clips were not necessary since little if any bleeding occurred and spontaneous resorption of the atrophied scrotum occurred rapidly. Sham operations resembled adrenalectomy in that a small incision was made on the lower dorsal surface of the animal under light ether anesthesia, the tissue below the incision palpated, and the wound closed with autoclips. Both gonadectomized and sham-operated animals were housed in groups of twenty for 1 week post-surgery 
prior to isolation. Adrenalectonized mice were maintained on laboratory chow and normal saline $(0.9 \%)$ in the drinking water. All other mice received tap water and laboratory chow ad libitum.

Conditioning of Avoidance Behavior

Training consisted of placing a mouse on an electrifiable grid floor in an aluminum chamber (8" $\times 10^{\prime \prime} \times 9 "$ ) containing a wooden shelf (4" $x$ 6" $\times 2 "$ ). Onset of a tone (conditioned stimulus, buzzer-58 decibels), operated manually, activated a timer which presented a continuous scrambled shock (1.0 ma) from a Grason Stadler shocker \#E1064Gs, 10 sec after onset of the tone. The shock and tone were terminated manually. Mice, after being placed on the grid, avoided shock by jumping onto the adjacent wooden shelf within $10 \mathrm{sec}$ after onset of the tone. This terminated the trial. Acquisition of the conditioned avoidance response consisted of 10 consecutive trials daily for 2 days. At the end of the twentieth trial 80-90\% of both grouped and isolated mice successfully avoided shock.

\section{Measurement of Avoidance Behavior}

On the morning of a drug test day, mice were given 5 consecutive trials, followed in the afternoon by a onetrial avoidance test, administered $30 \mathrm{~min}$ after intraperitoneal injection of chlorpromazine. Latency (sec) to avoidance after onset of the tone was recorded by a timer which was activated simultaneously. An interval of one day elapsed 
between drug treatments.

Statistical Methods

The students " $t$ " test for independent means, and Chi-square $2 \times 2$ contingency analysis (Dixon and Massey, 1969) were used to test for differences between control and experimental groups. Tests were performed on an 0livetti Underwood Programma 101 desk computer and the level of significance determined by comparison of " $t$ " and chisquare values with values from standard tables.

Determination of Whole-Body Levels of Barbiturates

At selected intervals after drug administration or immediately upon awakening, mice were sacrificed by cervical fracture and frozen in liquid nitrogen. The mice were then stored at $-10^{\circ} \mathrm{C}$ until assayed.

The method of Brodie et al (1953) was used to measure whole-body levels of barbiturates. The whole animal was homogenized in four volumes of ice cold $0.05 \mathrm{M}$ phosphate buffer $(\mathrm{pH} 5.5)^{1}$ in a Waring Blender at high speed $(19,000 \mathrm{RPM})$ for $5 \mathrm{~min}$ at $0-10^{\circ} \mathrm{C}$. A $4.0 \mathrm{ml}$ aliquot of the homogenate was transferred to $50 \mathrm{ml}$ centrifuge tubes containing $1.0 \mathrm{gm}$ sodium chloride. Thirty ml of washed petroleum ether (technical grade, B.P. $\left.37-47^{\circ} \mathrm{C}\right)^{2}$ contain-

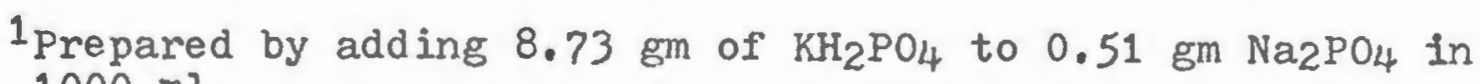
$1000 \mathrm{ml}$.

${ }^{2}$ Purified by washing with $1 \mathrm{~N} \mathrm{NaOH}, 1 \mathrm{~N} \mathrm{HCl}$ and two washings with triple distilled water. 
ing $1.5 \%$ isoamyl alcohol (reagent grade) was added and the mixtures were shaken mechanically for $45 \mathrm{~min}$ and centrifuged for $10 \mathrm{~min}$. Twenty $\mathrm{ml}$ aliquots of the solvent phase were transferred to clean tubes and shaken with $4.0 \mathrm{ml}$ of $0.8 \mathrm{M}$ phosphate buffer $(\mathrm{pH}-11)^{1}$ for $15 \mathrm{~min}$. The tubes were centrifuged and the petroleum ether removed by aspiration. The optical density of the unmetabolized barbiturate remaining in the aqueous phase was determined at $240 \mathrm{mu}$ (pentobarbital) or $245 \mathrm{mu}$ (hexobarbital) against pH 11 buffer on a Beckman DB-G grating spectrophotometer. Two parallel tubes were carried through the procedure, one containing $100 \mathrm{ug}$ of hexobarbital or pentobarbital with tissue obtained from an animal injected with distilled water and the other containing tissue from the same animal but no barbiturate added to serve as the blank. The concentration of unmetabolized barbiturate in the sample extract was compared with a standard solution prepared by dissolving $100 \mathrm{mg}$ of the barbiturate in sufficient distilled water to make $100 \mathrm{ml}$. A ten fold dilution was then made with $\mathrm{pH} 11$ buffer and the optical density of the resultant solution $(10 \mathrm{ug} / \mathrm{ml})$ was obtained. Recovery of barbiturates added to whole-body homogenate was $90-100 \%$ (hexobarbital) and $80 \%$ (pentobarbital).

1Prepared by adding $8.16 \mathrm{gm} \mathrm{NaOH}$ to $56.5 \mathrm{gm} \mathrm{Na2PO} 4 \mathrm{~s}$ $500 \mathrm{ml}$. 
Preparation of $9,000 \times G$ Supernatants

Mice were sacrificed by cervical dislocation, the livers quickly excised and gall bladders removed immediately. The tissue was chilled and kept at $0-4^{\circ} \mathrm{C}$ during all the subsequent procedures. The livers were weighed, minced with scissors and homogenized for $60 \mathrm{sec}$ in 3 volumes of ice cold $1.15 \% \mathrm{KCl}$ in a motor driven coaxial homogenizer using a teflon pestle. The homogenates were centrifuged for thirty minutes at $0^{\circ} \mathrm{C}$ and $10,000 \mathrm{rpm}$ (9,000 x G avg.) in an International Model B-60 Preparative Ultracentrifuge (rotor \#874). The supernate was decanted, strained through gauze, and the volume restored with $1.15 \% \mathrm{KCl}$ equal to that of the original homogenate. The supernatant fractions from control and experimental animals were stored at $-10^{\circ} \mathrm{C}$ until assayed.

Determination of In Vitro Metabolism of Hexobarbital

The method described by Cooper and Brodie (1953) was used to measure the disappearance of hexobarbital from incubation media. One $\mathrm{ml}$ of the $9,000 \times \mathrm{G}$ supernatant fraction prepared as described above was added to the incubation mixture containing 1.94 uMoles hexobarbital, 25 uMoles glucose-6-phosphate, 12 uMoles magnesium sulfate, 100 uMoles nicotinamide, 0.65 uMoles NADP and sufficient $0.1 \mathrm{M}$ phosphate buffer $\mathrm{pH} 7.4$ to make a final volume of $4.0 \mathrm{ml}$. Incubation was carried out in a Dubnoff metabolic shaker for $30 \mathrm{~min}$ at $37^{\circ} \mathrm{C}$ under room atmosphere. Two parallel incubation flasks were carried 
through the procedure, one containing $100 \mathrm{ug}$ hexobarbital with boiled tissue and the other containing tissue but not hexobarbital to serve as the blank. After incubation the flask volumes were transferred to $50 \mathrm{ml}$ centrifuge tubes containing $1.0 \mathrm{gm} \mathrm{NaCl}$ and $1.5 \mathrm{ml}$ phosphate buffer pH 5.5. The extraction procedure of Brodie et al (1953) was performed as described for whole-body levels of hexobarbital except that $10 \mathrm{ml}$ of $\mathrm{pH} 11$ buffer was used. Recovery of Hexobarbital added to boiled tissue was $100 \%$.

Determination of Methemoglobin Levels in Blood

The method of Evelyn and Malloy (1938) as modified by Vanderbelt et al (1944) was used to determine methemoglobin levels in blood. At selected intervals after sodium nitrite injection in mice, free flowing blood was collected from a neck incision into conical centrifuge tubes containing 2 drops of heparin solution (1:1000). Blood from control animals was collected in the same manner. A $0.2 \mathrm{ml}$ sample of blood was transferred immediately to test tubes containing $10 \mathrm{ml}$ of ice cold $0.02 \mathrm{M}$ phosphate buffer (pH 6.6) 1 and 2 drops of Triton X-100. The contents of the tubes were mixed thoroughly and allowed to stand for $5 \mathrm{~min}$ to permit complete hemolysis. Samples were kept at $0-4^{\circ} \mathrm{C}$ throughout the procedure to minimize decomposition and spontaneous decrease in met-

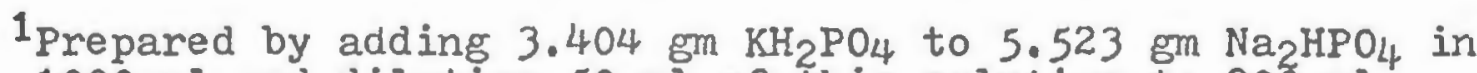
$1000 \mathrm{ml}$ and diluting $50 \mathrm{ml}$ of this solution to $200 \mathrm{ml}$. 
hemoglobin content. Samples were read at $630 \mathrm{mu}$ in a Beckman DU quartz spectrophotometer against a blank containing phosphate buffer ( $\mathrm{pH} 6.6)$. Two $4.0 \mathrm{ml}$ aliquots of each sample were transferred to two cuvettes and the absorbance determined at $630 \mathrm{mu}$. To one cuvette was then added approximately $4.0 \mathrm{mg}$ of sodium cyanide crystals, to the second cuvette an equal amount of potassium ferricyanide crystals and the contents mixed. The samples were read again at $630 \mathrm{mu}$. To the cuvette containing potassium ferricyanide was then added $4.0 \mathrm{mg}$ of sodium cyanide crystals and the absorbance of the solution deternined again at $630 \mathrm{mu}$. The methemoglobin content (\%) of the blood was calculated as the ratio of the decrease in absorbance obtained upon addition of sodium cyanide (conversion of methemoglobin to cyanomethemoglobin) as compared to the decrease in absorbance of a completely oxidized sample (potassium ferricyanide) converted to cyanomethemoglobin, multiplied by 100 .

Determination of Brain and Plasma Levels of Barbital $\mathrm{C}^{14}$ At selected intervals after exposure to hypobaric hypoxia or injection of sodium nitrite mice were administered barbital $\mathrm{c}^{14}(2.0 \mathrm{uc} / \mathrm{kg}, \mathrm{sp}$. act. $1.1 \mathrm{mc} / \mathrm{mMole})$ intraperitoneally or intravenously. In some experiments barbital $\mathrm{C}^{14}$ was injected in a $3 \%$ solution of unlabelled barbital $(300 \mathrm{mg} / \mathrm{kg})$ in order to investigate the effect of barbiturate anesthesia on drug distribution.

Mice were sacrificed by exsanguination via a neck 
incision (approximately $30 \mathrm{sec}$ ) and free flowing blood collected in conical centrifuge tubes containing two drops if heparin solution $(1,1000)$. Plasma was obtained by immediate centrifugation for $10 \mathrm{~min}$ at $3700 \mathrm{rpm}$ (2000xg). A $0.1 \mathrm{ml}$ aliquot of plasma was transferred to $15 \mathrm{ml}$ of scintillator solution ${ }^{1}$ and counted in a Packard model 3310 Liquid Scintillation Spectrometer for $50 \mathrm{~min}$ or sufficient time to accumulate 10,000 counts $^{2}$. Whole brains including lower portions of the medulla were rapidly excised, weighed and homogenized in 3 volumes of triple distilled water. one-half $\mathrm{ml}$ of homogenate was transferred to a scintillation vial containing $2.5 \mathrm{ml}$ of Nuclear Chicago Solubilizer (NCS) and the brain tissue digested at $50^{\circ} \mathrm{C}$ for $16 \mathrm{~h}$ in a Dubnoff metabolic incuba-

1Prepared by dissolving 6 gm PPO (2,5-diphenyloxazole) and $200 \mathrm{ml}$ BBS-3 (Beckman Biosolv 3) in sufficient toluene to make 1.0 liter. Two drops of $4 \% \mathrm{SnCl}_{2}$ in $0.1 \mathrm{~N} \mathrm{HCl}$ was added to each vial before addition of plasma.

2 The standard deviation of the counting rate of samples counted by this procedure was $5 \%$ or less. The standard deviation was calculated using the following formula (Wang and Willis, 1965).

$$
\sigma_{s}=\sqrt{\frac{r_{g}+r_{b}}{t_{g}}-\frac{t_{b}}{t^{2}}}
$$

where:

$$
\begin{aligned}
& r_{g}=\text { counting rate of sample } \\
& r_{b}=\text { counting rate of background } \\
& t_{g}=\text { time the sample was counted }
\end{aligned}
$$$$
t_{b}=\text { time background was counted }
$$

$$
\sigma s=\begin{gathered}
\text { standard deviation } \\
\text { of sample }
\end{gathered}
$$


tor shaker. Fifteen $m$ l of scintillation solution ${ }^{1}$ was added to the digestant and the sample counted as previously described. All samples were corrected for background and are reported as DPM of barbital $\mathrm{c}^{14}$ calculated by use of channels ratio.

1Prepared by dissolving $6 \mathrm{gm}$ PPO (2,5 diphenyloxazole) in sufficient toluene to make 1.0 liter. 


\section{RESULTS}

Effect of Hypoxia on Drug-Induced Narcosis

The effect of acute exposure to hypobaric hypoxia on drug-induced narcosis is summarized in Table 1. Narcosis was prolonged under the hypobaric environment in both mice and rats. The effect was significant in all cases except in rats in which prolongation of pentobarbital narcosis did not reach statistical significance. The magnitude of the effect produced by hypobaric hypoxia differed greatly in mice and rats. The comparison illustrated in Table 1 shows that in the case of barbital, increase in narcosis time was nearly 20-fold greater in mice; the effect on pentobarbital or chloral hydrate was 5-fold greater. The duration of pentobarbital narcosis was markedly increased by acute exposure of mice to $10 \%$ oxygen at normal pressure as well as to hypobaric hypoxia (Table 2).

Effect of Hypoxia on Body Temperature

The rectal temperature of mice exposed to the hypobaric environment dropped at a rate of $0.1 \% \mathrm{~min}$ reaching a maximum drop of $5.8^{\circ}$ at $90 \mathrm{~min}$ of exposure. The rate of temperature drop was only half this in rats and reached a maximum of only $2.5^{\circ}$ (Figure 2). The rectal temperature of 2 mice and 2 rats restrained in the hypo.. 
TABLE 1

EFFECT OF HYPOBARIC EXPOSURE ON DRUG-INDUCED NARCOSIS

\begin{tabular}{|c|c|c|c|c|}
\hline \multirow[b]{2}{*}{ Drug } & \multirow{2}{*}{$\begin{array}{c}\text { Dose } \\
(\mathrm{mg} / \mathrm{kg})\end{array}$} & \multicolumn{2}{|c|}{ Narcosis, $\min \pm S . E .(N)$} & \multirow{2}{*}{$\begin{array}{c}\% \\
\text { Increase }\end{array}$} \\
\hline & & Control & Hypobarict & \\
\hline \multicolumn{5}{|l|}{ Mice } \\
\hline Barbital & 300 & $91 \pm 9.2(10)$ & $584^{+}-44^{a}(11)$ & 540 \\
\hline Pentobarbital & 50 & $90 \pm 8.4(12)$ & $148 \pm 14^{b}(11)$ & 65 \\
\hline Chloral Hydrate & 350 & $105^{+6.6(13)}$ & $206_{-1}^{ \pm} 7^{2}(13)$ & 96 \\
\hline \multicolumn{5}{|l|}{ Rats } \\
\hline Barbital & 200 & $244 \pm 10 \cdot 5(23)$ & $304 \pm 24^{c}(19)$ & 25 \\
\hline Pentobarbital & 35 & $56 \pm 2.7(12)$ & $62 \pm 3 \cdot 7(11)$ & 11 \\
\hline Chloral Hydrate & 300 & $75 \pm 3.0 \quad(10)$ & $91 \pm 3.9(11)$ & 21 \\
\hline
\end{tabular}

$1364 \mathrm{~mm} \mathrm{Hg}$ equivalent to $10 \%$ ambient oxygen

Control vs, hypobaric;

$$
\begin{aligned}
& a_{p}<0.001 \\
& b_{p}<0.01 \\
& c_{p}<0.05 \\
& d_{p}>0.05
\end{aligned}
$$


TABIE 2

EFFECT OF HYPOXIA ON DURATION OF PENTOBARBITAL ${ }^{a}$ NARCOSIS

\begin{tabular}{|c|c|c|c|}
\hline Mode of Hypoxia & $\frac{\text { Narcosis, }}{\text { Control }}$ & $\frac{\mathrm{n} \pm \mathrm{S} \cdot \mathrm{E} \cdot(\mathrm{N})}{\text { Нурохic }}$ & $\mathrm{P}$ \\
\hline $10 \%$ oxygen $^{\mathrm{b}}, 760 \mathrm{~mm} \mathrm{Hg}$ & $23 \pm 2.6(12)$ & $47 \pm 2.9(13)$ & $<0.001$ \\
\hline Airc, $364 \mathrm{~mm} \mathrm{Hg}$ & $32 \pm 2.4(11)$ & $57 \pm 4.5$ (9) & $<0.001$ \\
\hline
\end{tabular}

a $50 \mathrm{mg} / \mathrm{kg}(200 \mathrm{muM} / \mathrm{g})$ injected intraperitoneally.

$\mathrm{b}_{10 \%}$ oxygen in nitrogen mixture at normal pressure.

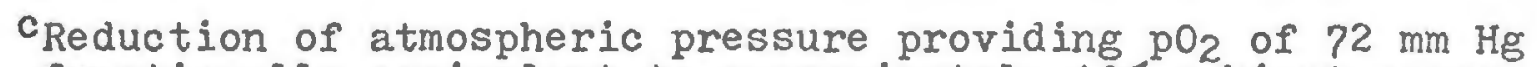
functionally equivalent to approximately $10 \%$ ambient oxygen. 


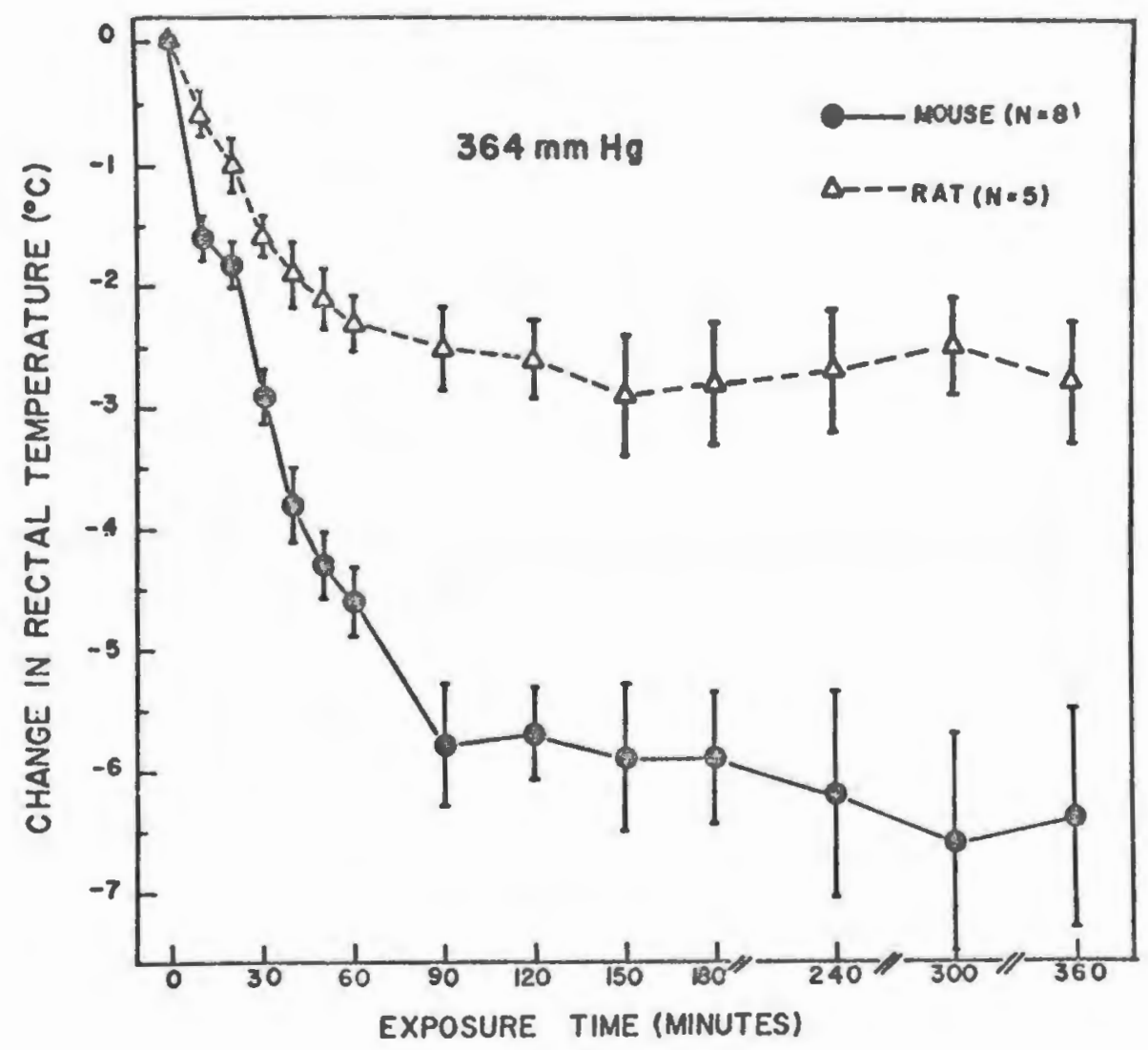

Figure 2. RECTAL TEMPERATURE OF MICE AND RATS EXPOSED TO THE HYPOBARIC ENVIRONMENT. 
baric chamber under room atmosphere declined less than $1^{\circ}$ in 6 hours.

Effect of Hypoxia and Ambient Temperature on Drug-Induced Hypothermia and Narcosis

Figure 3 demonstrates that mice maintain normal body temperature during exposure to hypoxia at $30^{\circ} \mathrm{C}$ ambient temperature. Reduction of body temperature in mice under the influence of pentobarbital or chloral hydrate narcosis was enhanced and prolonged during hypoxia at either 22 or $30^{\circ} \mathrm{C}$ (Figures 4 and 5 ). The extensive hypothermia due to barbital during hypoxia at $22^{\circ} \mathrm{C}$ was almost completely prevented at $30^{\circ} \mathrm{C}$ (Figure 6).

Exposure of mice to hypoxia at $30^{\circ} \mathrm{C}$ after pentobarbital injection did not alter the enhancement of pentobarbital narcosis seen at $22^{\circ} \mathrm{C}$, while potentiation of the. chloral hydrate effect was reduced by $50 \%$. However, potentiation of narcosis due to barbital under hypoxia at $22^{\circ} \mathrm{C}$ was greatly reduced at $30^{\circ} \mathrm{C}$ (Table 3 ).

Effect of Hypoxia on Drug-Induced Convulsions

The incidence of convulsions due to intraperitoneal semicarbazide, m-fluorotyrosine or methionine sulphoximine were markedly reduced in the mice exposed to $364 \mathrm{~mm} \mathrm{Hg}$ $\left(10 \% 0_{2}\right)$ (Figures $\left.7-9\right)$. In the case of methionine sulphoximine, the anticonvulsant effect at $280 \mathrm{~mm} \mathrm{Hg}\left(7.5 \% \mathrm{O}_{2}\right)$ was greater after $8 \mathrm{~h}(p<0.02)$ than at $364 \mathrm{~mm} \mathrm{Hg}$. In addition, lethality due to m-fluorotyrosine was extensively decreased during hypoxia. 


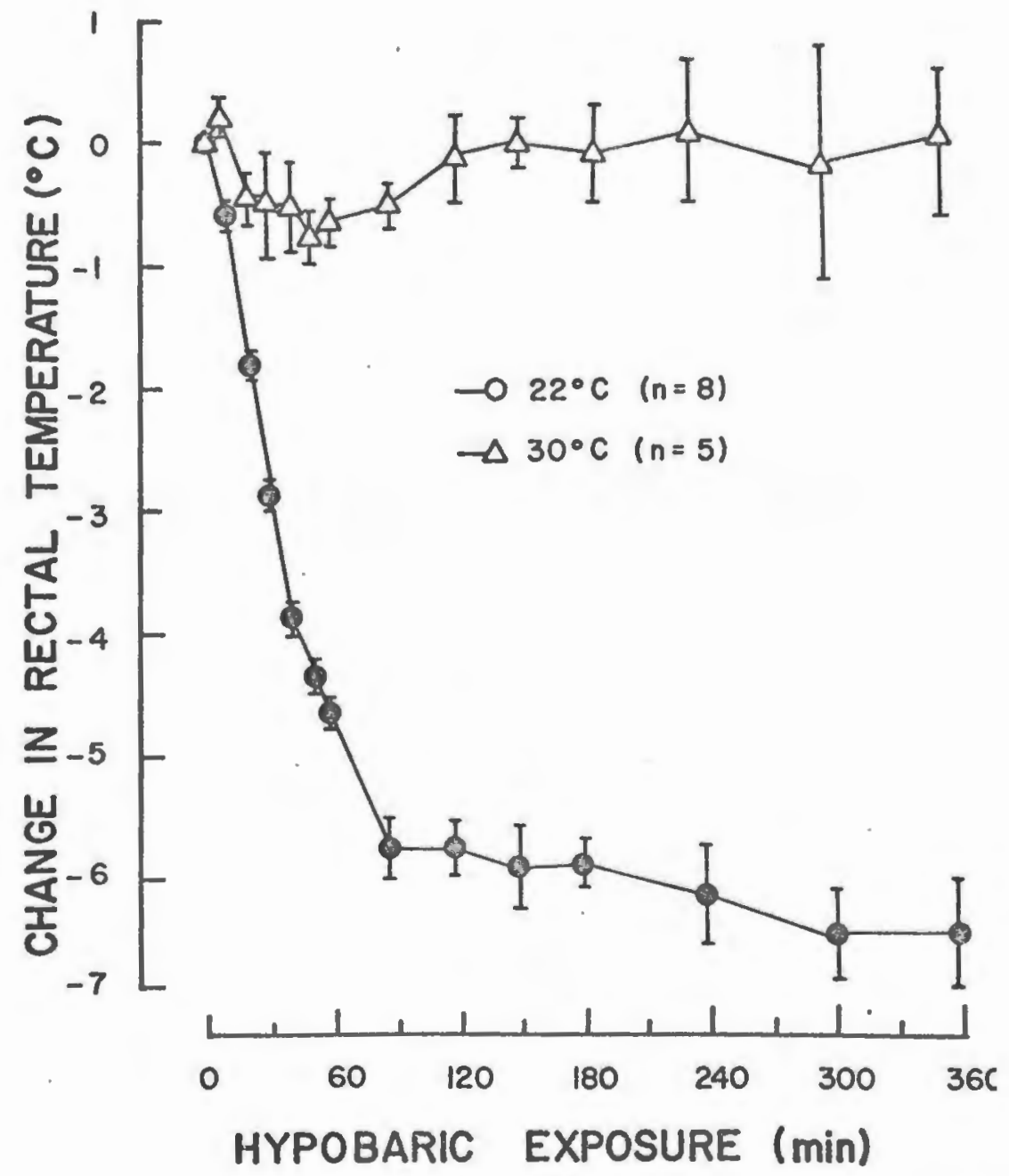

Figure 3. EFFECT OF AMBIENT TEMPERATURE ON THE HYPOTHERMIA DURING HYPOXIA IN WICE. 


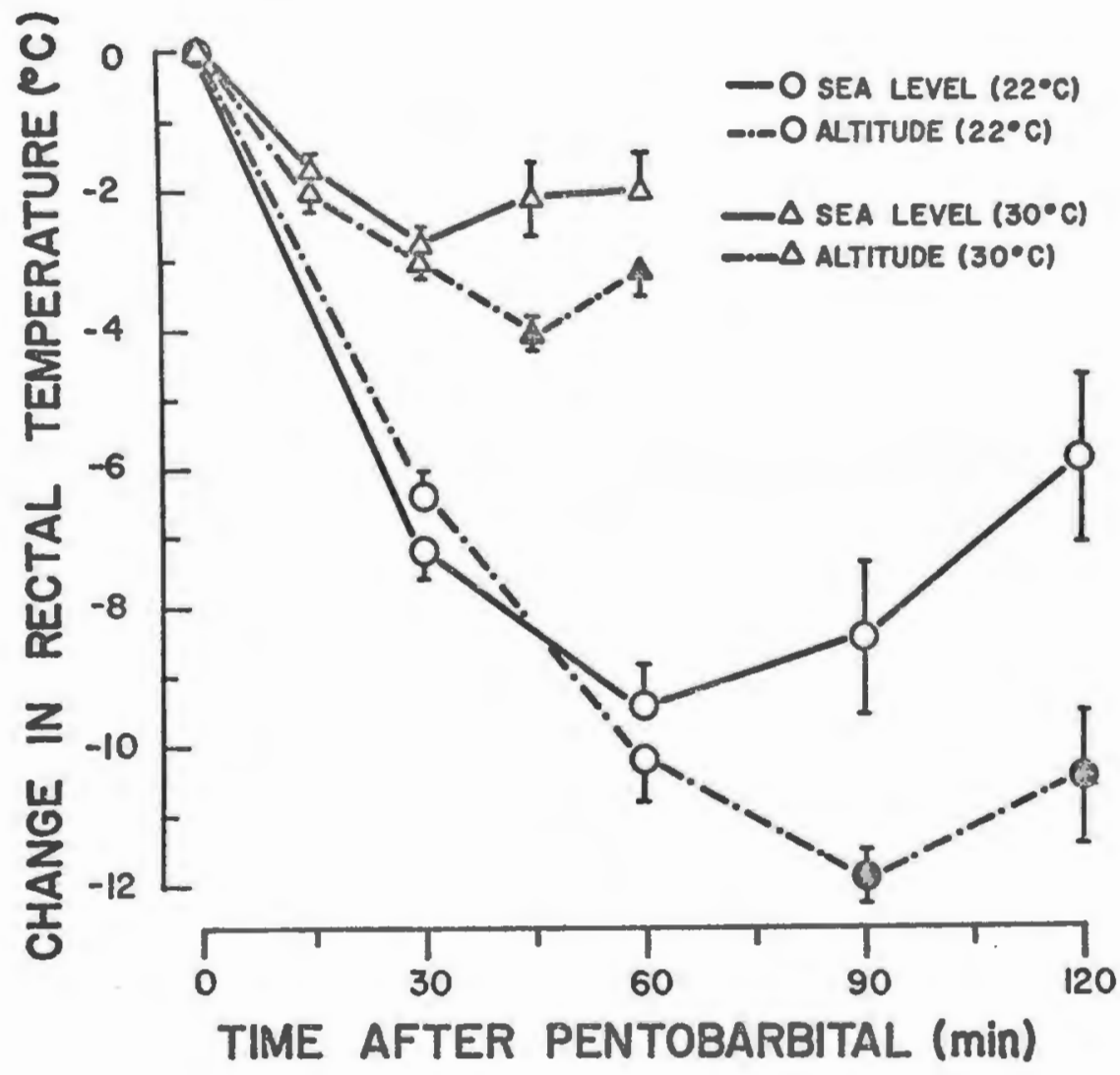

Figure 4. EFFECT OF HYPOXIA AND ANBIENT TEMPERATURE ON PENTOBARBITAL-INDUCED HYPOTHERMIA IN MICE. Sea level $\left(760 \mathrm{~mm} \mathrm{Hg}, 21 \% \mathrm{O}_{2}\right)$. Altitude $\left(364 \mathrm{mn} \mathrm{Hg}, 10 \% \mathrm{o}_{2}\right)$. Each point represents mean $\pm S . E$. of 6 animals. Opaque symbols indicate significant difference $(p<0.01)$ from sea level controls. 


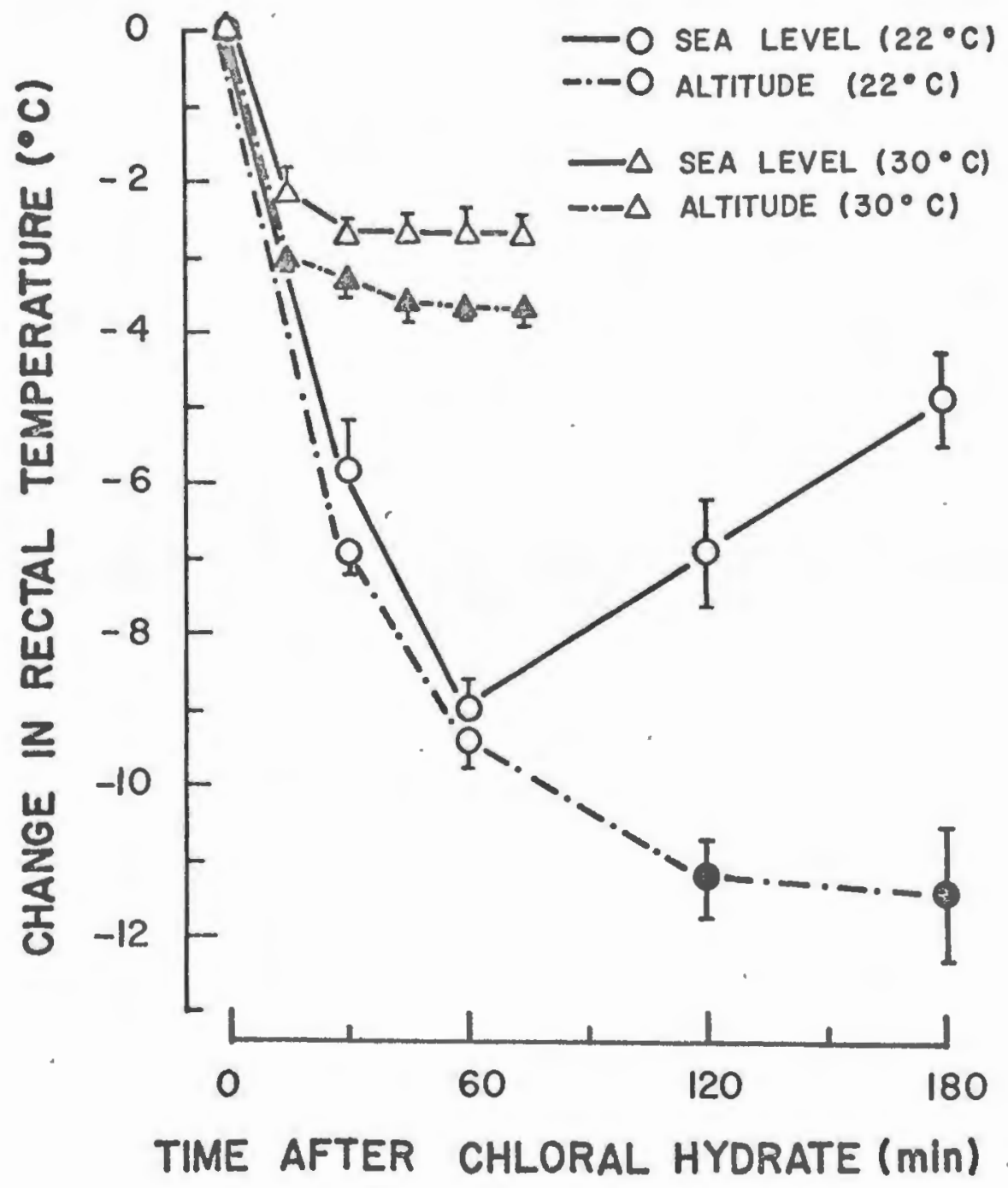

Figure 5. EFFECT OF HYPOXIA AND APBIENT I'EMPERATURE ON CHLORAL HYDRATE-INDUCED HYPOTHERMIA IN MICE. Sea level $\left(760 \mathrm{~mm} \mathrm{Hg}, 21 \% \mathrm{O}_{2}\right)$. Altitude $\left(364 \mathrm{~mm} \mathrm{Hg}, 10 \% \mathrm{O}_{2}\right)$. Each point represents mean \pm S.E. of 6 animals. Opaque symbols denote significant difference $(p<0.01)$ from sea level controls. 


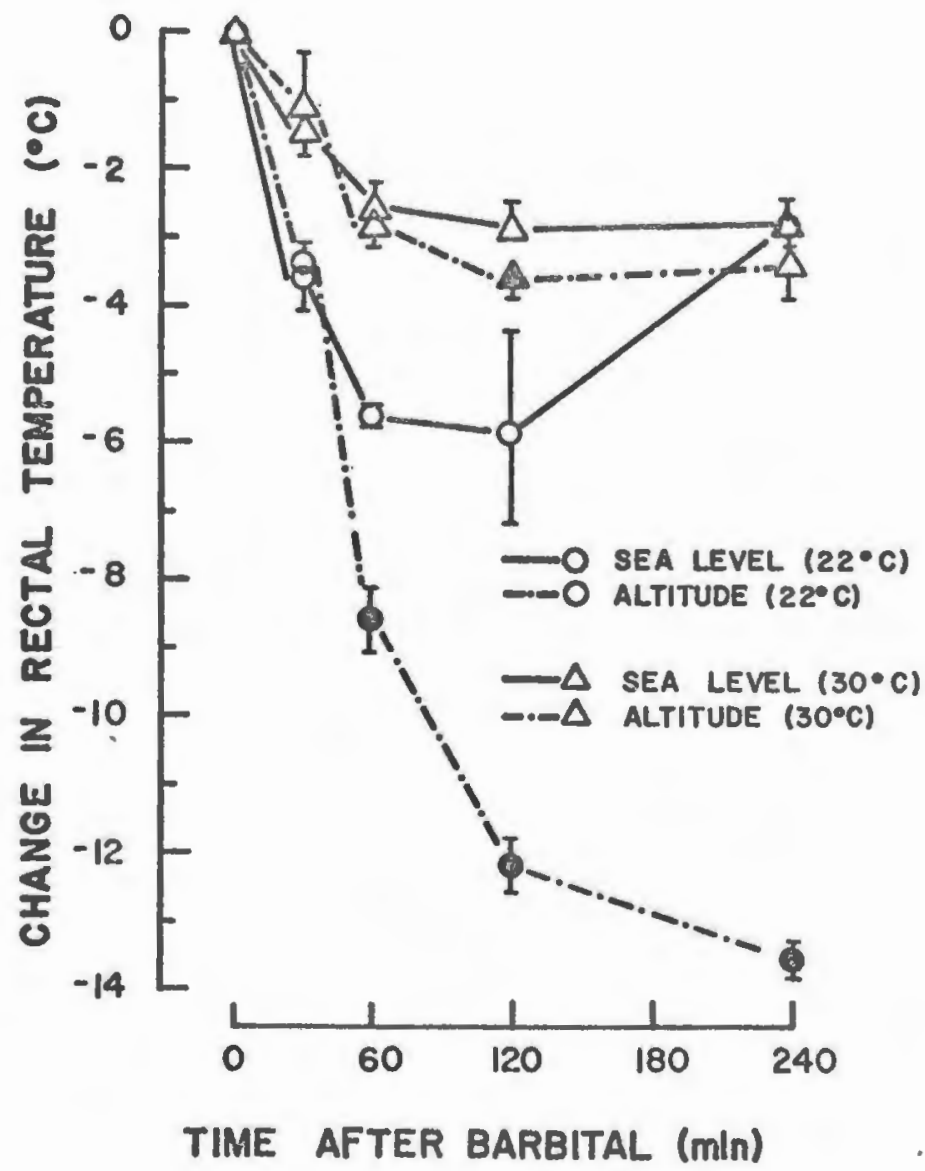

Figure 6. EFFECT OF HYPOXIA AND ANB IENT TEMPERATURE ON BARBITAL-INDUCED HYPOTHERMIA IN HICE. Sea level $(760 \mathrm{~mm} \mathrm{Hg}$, $\left.21 \% \mathrm{O}_{2}\right)$. Altitude $\left(364 \mathrm{~mm} \mathrm{Hg}, 10 \% \mathrm{O}_{2}\right)$. Each point represents mean \pm S.E. of 6 animals. Opaque symbols denote significant difference (p 0.01) from sea level controls. 
TABIE 3

EFFECT OF HYPOBARIC HYPOXIA ON DRUG-INDUCED NARCOSIS AT TWO AMBIENT TEMPERATURES

\begin{tabular}{|c|c|c|c|c|}
\hline $\begin{array}{l}\text { Drug } \\
\text { (mg/kg) }\end{array}$ & $\begin{array}{c}\text { Ambient } \\
\text { Temp: } \\
\left({ }_{0} \mathrm{C}\right)\end{array}$ & $\frac{\text { Narcosis, }}{\text { Control }}$ & $\frac{\min \pm \text { S.E. }(\mathrm{N})}{\text { Hypobaric }}$ & $\begin{array}{c}\% \\
\text { Increase }\end{array}$ \\
\hline \multirow{2}{*}{$\begin{array}{l}\text { Barbital } \\
(300)\end{array}$} & 22 & $91 \pm 9.2(10)$ & $584 \pm 44^{a}(11)$ & 540 \\
\hline & 30 & $178 \pm 15 \quad$ (12) & $349 \pm 12^{\mathrm{a}}(11)$ & 96 \\
\hline \multirow{2}{*}{$\begin{array}{l}\text { Pentobarbital } \\
(50)\end{array}$} & 22 & $90 \pm 8.4$ (12) & $148 \pm 14 \mathrm{~b}(11)$ & 65 \\
\hline & 30 & $38_{-3}^{ \pm} .0(20)$ & $72 \pm 7.0(18)$ & 89 \\
\hline \multirow{2}{*}{$\begin{array}{l}\text { Chloral Hydrate } \\
(350)\end{array}$} & 22 & $105 \pm 6.6(13)$ & $206 \pm 17^{a}(13)$ & 96 \\
\hline & 30 & $55 \pm 4.9(12)$ & $85 \pm 5.4(14)$ & 55 \\
\hline
\end{tabular}

$1364 \mathrm{~mm} \mathrm{Hg}$ equivalent to $10 \%$ ambient oxygen.

Control vs. hypobaric;

$a_{p}<0.001$

$b_{p}<0.01$ 


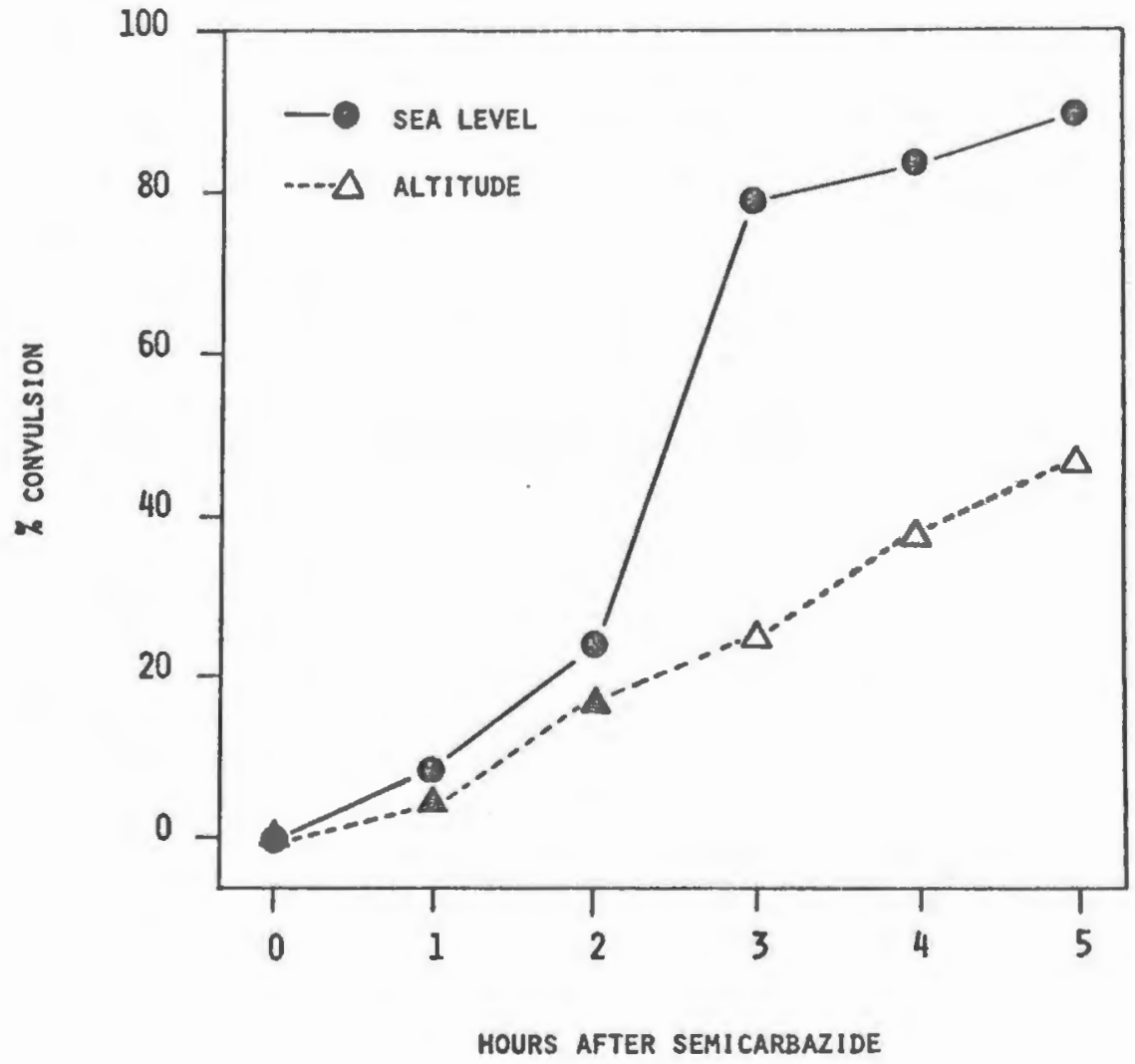

Figure 7. EFFECT OF HYPOBARIC HYPOXIA ON SEMICARBAZIDE (200 mg/kg intraperitoneally) CONVULSIONS. Sea level $\left(760 \mathrm{~mm} \mathrm{Hg}, 21 \% \mathrm{O}_{2}\right)$. Altitude $\left(364 \mathrm{~mm} \mathrm{Hg}, 10 \% \mathrm{O}_{2}\right)$. Each point represents cumulative \% convulsed out of 24 mice. Open symbols denote significant difference $(p<0.005)$ from sea level controls. 


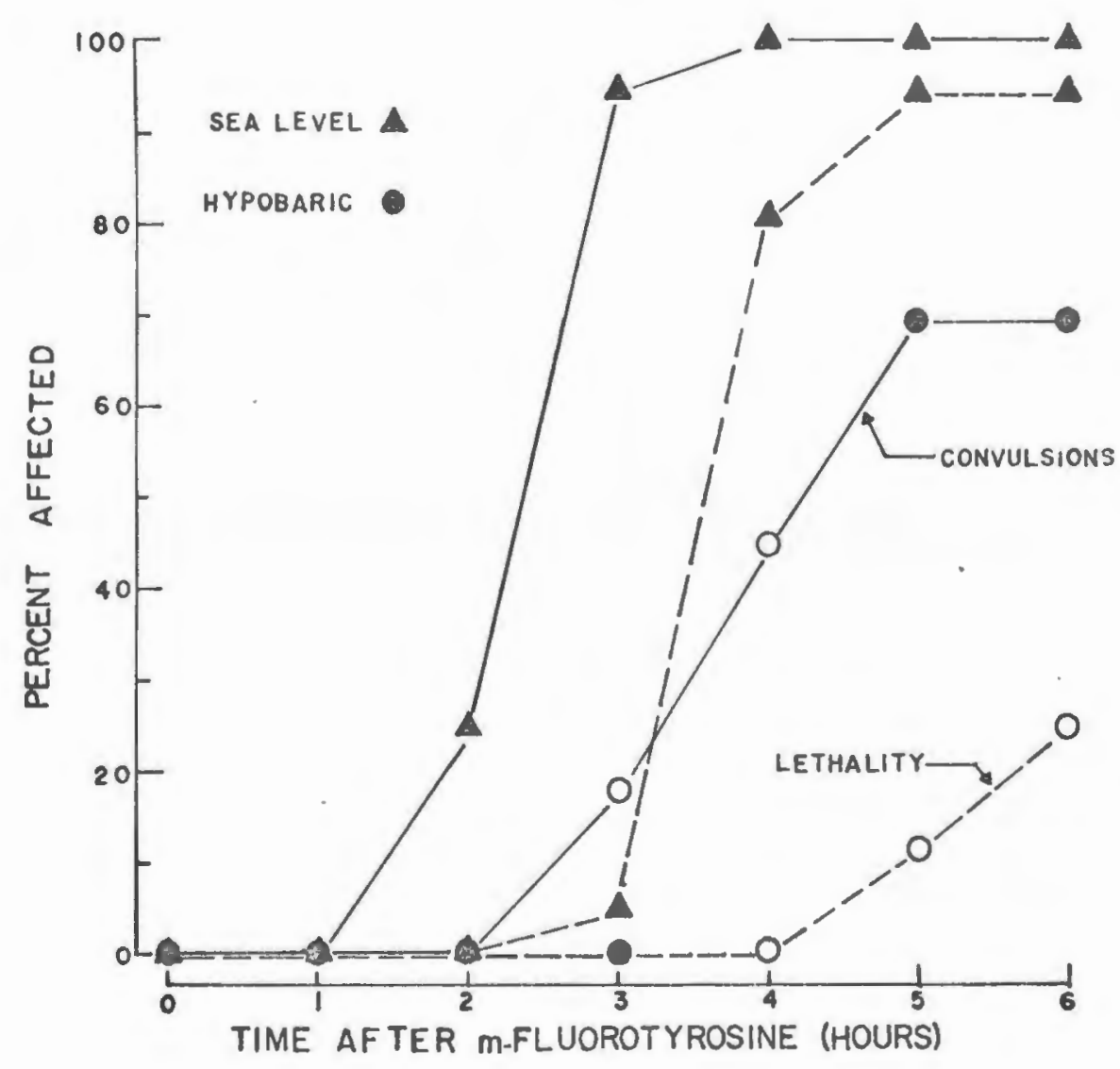

Figure 8. EFFECT OF HYPOBARIC HYPOXIA ON M-FLUOROTYROSINE (10 mg/ $\mathrm{kg}$ intraperitoneally) CONVULSIONS AND IETHALITY. Sea level $\left(760 \mathrm{~mm} \mathrm{Hg}, 21 \% \mathrm{O}_{2}\right)$. Hypobaric $\left(364 \mathrm{~mm} \mathrm{Hg}, 10 \% \mathrm{O}_{2}\right)$. Each point represents cumulative \% convulsed out of 16 mice. Open symbols denote significant difference $(p<0.005)$ from sea level controls. 


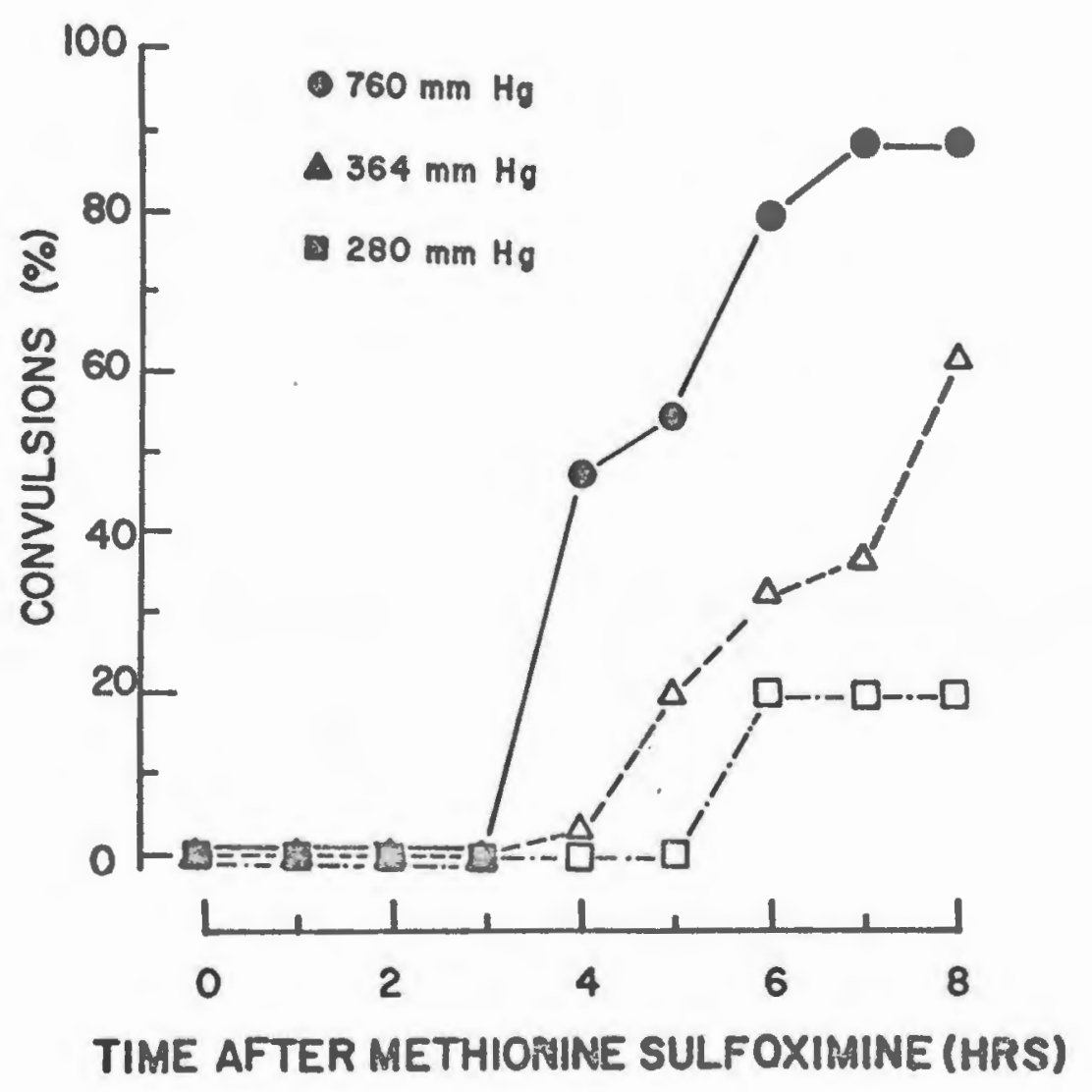

Figure 9. EFFECT OF HYPOBARIC HYPOXIA ON METHIONINE SULPHOXIMINE (200 mg/kg intraperitoneally) CONVUISIONS. $760 \mathrm{~mm} \mathrm{Hg}$ $\left(21 \% \mathrm{O}_{2}\right) \cdot 364 \mathrm{~mm} \mathrm{Hg}\left(10 \% \mathrm{O}_{2}\right) \cdot 280 \mathrm{~mm} \mathrm{Hg}\left(7.5 \% \mathrm{O}_{2}\right)$. Each point represents cumulative $\%$ convulsed out of 24 mice. Open symbols denote significant difference $(p<0.005)$ from sea level (760 mm Hg) controls. 
Exposure of mice to hypobaric hypoxia or injection of sodium nitrite antagonized seizures produced by intracerebral semicarbazide (Figure 10 ). Mice receiving only distilled water $(0.01 \mathrm{ml} / \mathrm{mouse})$ intracerebrally did not show any sign of convulsions and resumed normal activity in less than 2 min after injection.

Effect of Hypobaric Hypoxia on Disappearance of Body Pentobarbital and Pentobarbital Concentration At Awakening

The mice under acute hypobaric conditions showed lower levels of pentobarbital in the body at the time of awakening than did the control mice at room atmosphere. Further, pentobarbital concentration in the body declined at a slower rate in the mice exposed to hypobaric hypoxia (Table 4).

Effect of Sodium Nitrite on Blood Methemoglobin, Body Temperature and Barbiturate Narcosis

The potentiation of hexobarbital narcosis by sodium nitrite showed a temporal correlation with hypothermia and methemoglobin produced by the drug (Figure 11). The peak effect on all 3 parameters occurred approximately $30 \mathrm{~min}$ after nitrite injection (Figure 11).

Hypothermia due to sodium nitrite at $22^{\circ} \mathrm{C}$ was prevented at $30^{\circ} \mathrm{C}$ ambient temperature. Nitrite-induced enhancement of hexobarbital narcosis at $22^{\circ} \mathrm{C}$ was unaffected at $30^{\circ} \mathrm{C}$. However, the potentiation of barbital narcosis by sodium nitrite at $22^{\circ}$ was absent at the higher ambient temperature (Table 5). 


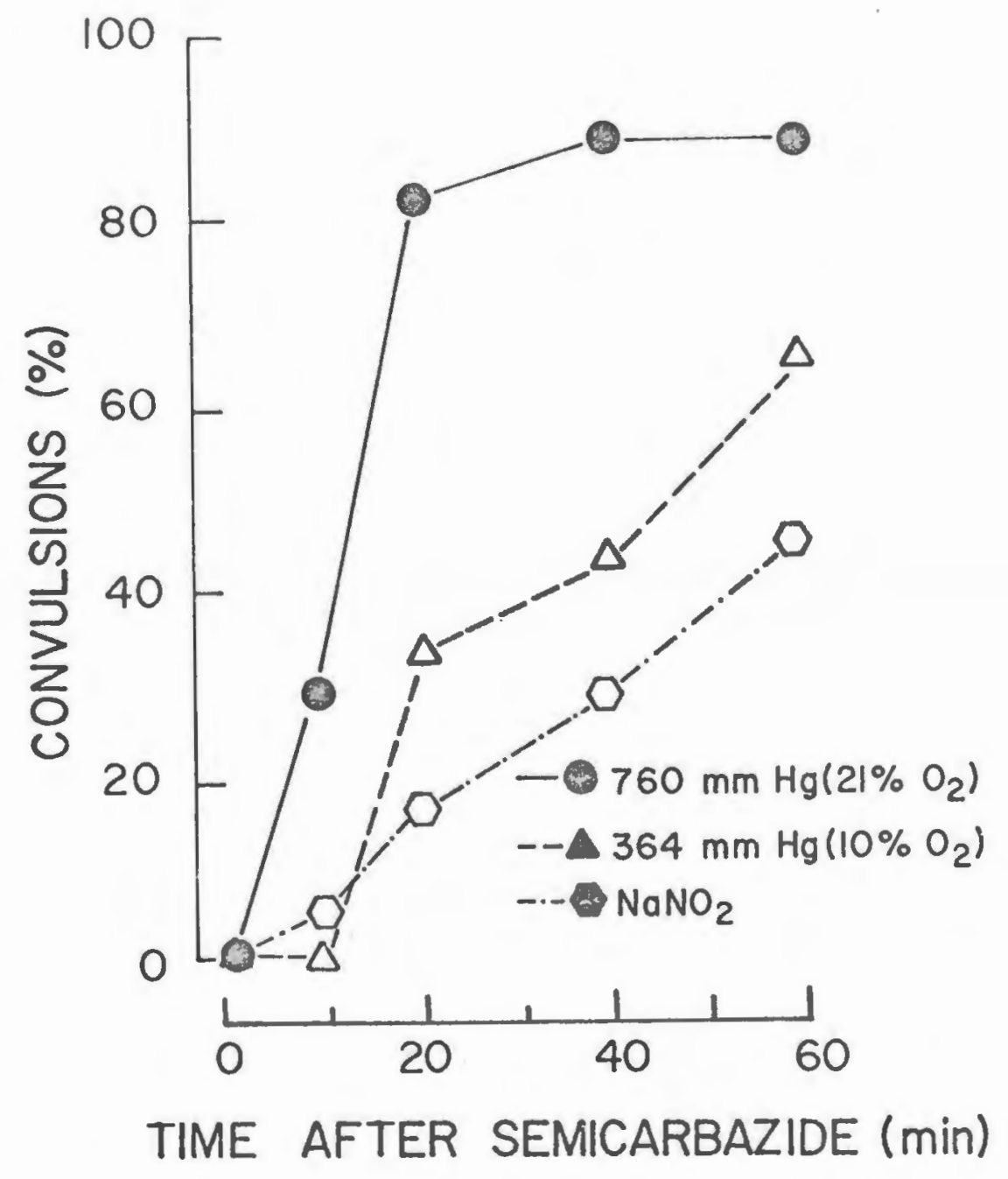

Figure 10. EFFECT OF HYPOBARIC HYPOXIA AND SODIUM NITRITE (100 mg. kg, subcutaneously) ON CONVULSIONS FOLIOWING INTRACEREBRAL INJECTION OF SEMICARBAZIDE. Each point represents cumulative \% convulsed out of 16-37 mice. Clear symbols denote significant difference $(p<0.01)$ from room atmosphere $(760 \mathrm{~mm} \mathrm{Hg})$ controls. 
TABLE 4

EFFECT OF HYPOBARIC HYPOXIA ON DISAPPEARANCE OF BODY PENTOBARBITAL AND PENTOBARBITAL CONCENTRATION AT AWAKENING Time after
pentobarbital muM pentobarbital/g body weight, $\quad P$ $\frac{\text { mean } \pm \text { S.E. }(N)}{\text { Control }}$

\begin{tabular}{|c|c|c|c|}
\hline At awakening & $80 \pm 9.0$ (8) & $47 \pm 8.0$ (8) & $<0.01$ \\
\hline $20 \mathrm{~min}$ & $123_{-13}^{+13}$ & $146 \pm 20$ & $>0.05$ \\
\hline $40 \mathrm{~min}$ & $51 \pm 15$ & $89 \pm 13$ & $<0.05$ \\
\hline
\end{tabular}

$a_{50} \mathrm{mg} / \mathrm{kg}(200 \mathrm{muM} / \mathrm{g})$ injected intraperitoneally.

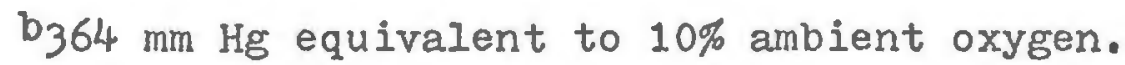




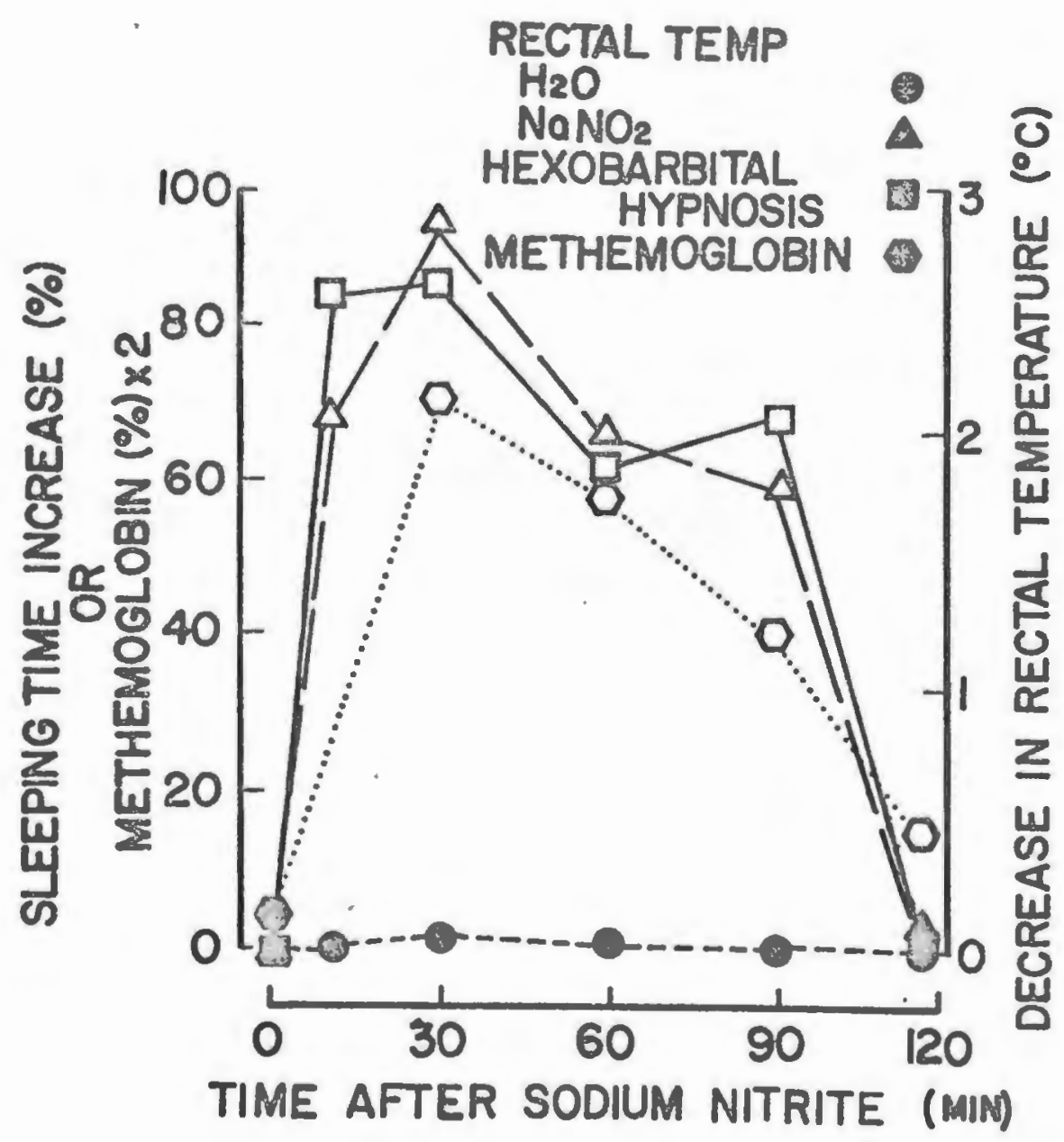

Figure 11. TIME COURSE OF EFFECT OF SODIUM NITRITE (100 mg/ $\mathrm{kg}$, subcutaneously) ON HEXOBARBITAL (120 mg/kg, intraperitoneally) NARCOSIS, BODY TEMPERATURE AND BLOOD METHEMOGLOBIN. Clear symbols denote significant difference $(p<0.05)$ from 0 or $120 \mathrm{~min}$ values. 


\section{TABLE 5}

EFFECT OF SODIUM NITRITE ON BODY TEMPERATURE AND BARBITURATE NARCOSIS AT TWO AMBIENT TEMPERATURES

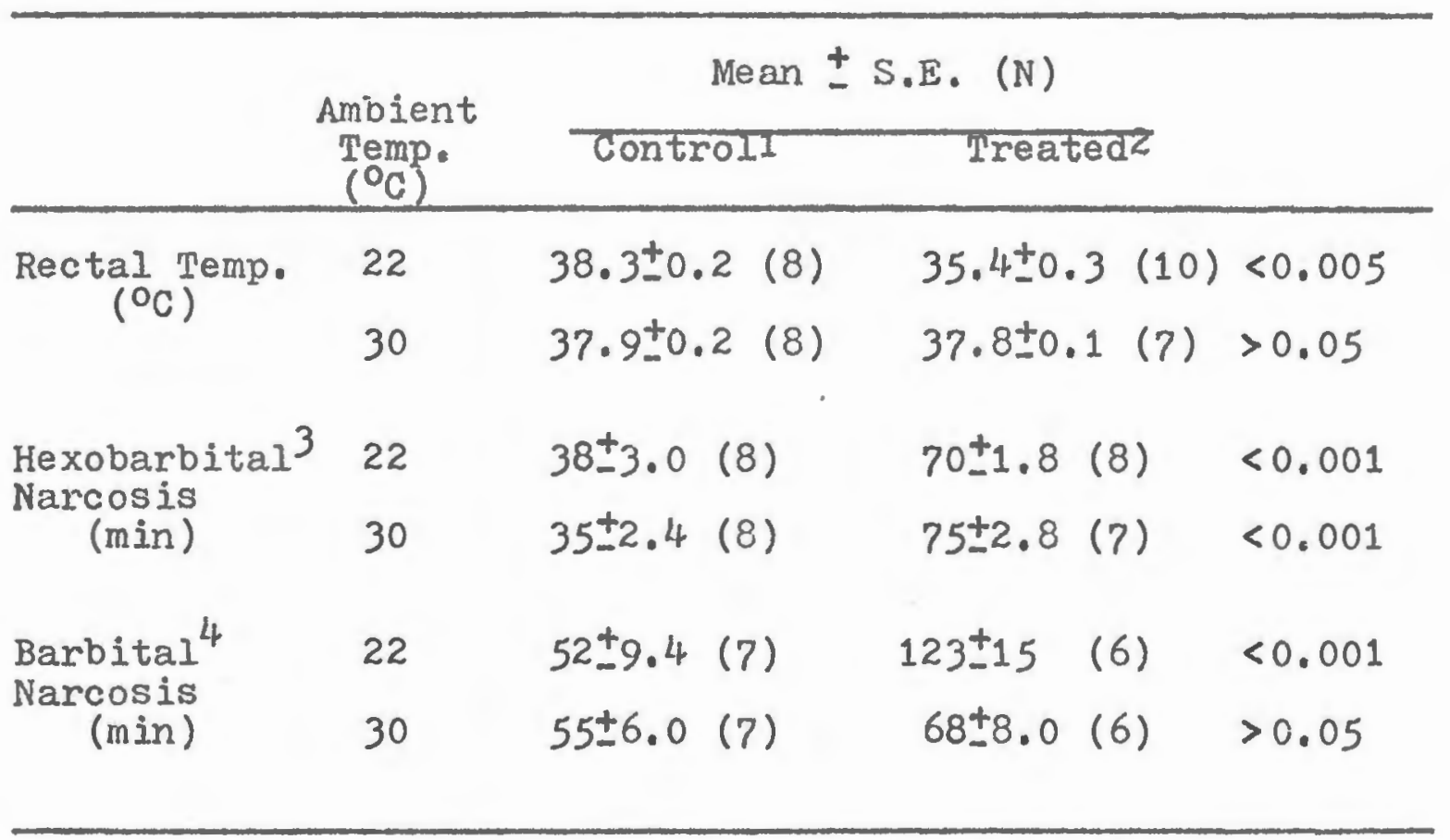

1Distilled water $(10 \mathrm{ml} / \mathrm{kg}$ ) injected subcutaneously $30 \mathrm{~min}$ prior to barbiturate injection.

2 Sodium nitrite $(100 \mathrm{mg} / \mathrm{kg}$ ) injected subcutaneously $30 \mathrm{~min}$ prior to barbiturate injection.

$3120 \mathrm{mg} / \mathrm{kg}$ injected intraperitoneally.

$4300 \mathrm{mg} / \mathrm{kg}$ " 
Effect of Sodjum Nitrite on Disappearance of Body Hexobarbital and Hexobarbital Concentration At Awakening

The decline of hexobarbital in the whole-body of nitrite-treated mice was slower than in the control animals receiving distilled water. In addition, mice receiving sodium nitrite gained righting reflex at lower levels of barbiturate than their respective controls (Table 6).

Effect of Intracerebral Sodium Nitrite on Body Temperature and Hexobarbital iNarcosis

Sodium nitrite administered intracerebrally to mice (50 ug/mouse) did not affect hexobarbital narcosis or significantly alter body temperature (Table 7).

Effect of Sodium Nitrite on Hexobarbital Oxidase Activity Sodium nitrite added to the incubation media in a concentration approximating that administered in vivo $\left(9.05 \times 10^{-5} \mathrm{M}, 100 \mathrm{ug} / \mathrm{g}\right)$ did not affect the metabolism of hexobarbital by $9,000 \times \mathrm{g}$ supernatant. Although one-half this concentration $\left(4.53 \times 10^{-5} \mathrm{M}, 50 \mathrm{ug} / \mathrm{g}\right)$ showed a stimulating effect on hexobarbital metabolism, this effect seemed unimportant since the two higher concentrations utilized did not alter hexobarbital oxidase activity (Table 8).

Effect of Methylene Blue on Nitrite-Induced Methemoglobinemia and Enhancement of Hexobarbital Narcos is

Sodium nitrite injected subcutaneously (100 mg/ $\mathrm{kg}$ ) increased methemoglobin concentration approximately 10-fold 


\section{TABLE 6}

EFFECT OF SODIUM NITRITE ON DISAPPEARANCE OF BODY HEXOBARBITAL AND HEXOBARBITAL CONCENTRATION AT AWAKENING

Time after hexobarbitala
muM hexobarbital/g body weight mean \pm S.E. (N)
$P$

Controlo Treatedc

\begin{tabular}{lcrll}
\hline At awakening & $130 \pm 11(6)$ & $67 \pm 10(7)$ & $<0.005$ \\
$20 \mathrm{~min}$ & $156 \pm 22(7)$ & $320 \pm 18(8)$ & $<0.005$ \\
$40 \mathrm{~min}$ & $37 \pm 6(7)$ & $125 \pm 18(8)$ & $<0.01$ \\
\hline
\end{tabular}

$a_{120} \mathrm{mg} / \mathrm{kg}$ (550 muM $/ \mathrm{g}$ ) injected intraperitoneally.

$b_{\text {Distilled water }}(10 \mathrm{ml} / \mathrm{kg})$ injected subcutaneously $30 \mathrm{~min}$ prior to hexobarbital.

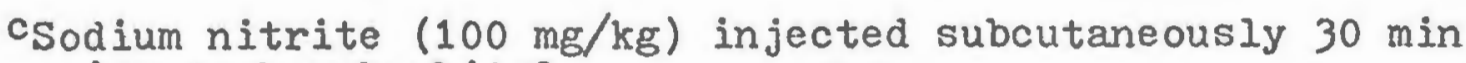
prior to hexobarbital. 


\section{TABLE $?$}

EFFECT OF INTRACEREBRAL SODIUM NITRITE ON BODY TEMPERATURE AND HEXOBARBITAL NARCOSIS

\begin{tabular}{|c|c|c|c|}
\hline & \multicolumn{2}{|c|}{ Mean $\pm S . E .(N)$} & $\mathrm{P}$ \\
\hline${ }_{\left({ }^{\circ} \mathrm{C}\right)}^{\text {Rectal Temp. }}{ }^{3}$ & $38.05 \pm 0.2(8)$ & $38.04 \pm 0.2(7)$ & $>0.05$ \\
\hline$\underset{(\text { min })}{\text { Sleeping }}$ Time $^{4}$ & $54 \pm 4.0(9)$ & $55 \pm 6.0(9)$ & $>0.05$ \\
\hline
\end{tabular}

1Distilled water $(0.01 \mathrm{ml} /$ mouse) injected intracerebrally. 2 Sodium nitrite $(50 \mathrm{ug} /$ mouse) injected intracerebrally. 3 Measured $30 \mathrm{~min}$ after intracerebral injection.

$4120 \mathrm{mg} / \mathrm{kg}$ hexobarbital injected intraperitoneally immediately after intracerebral injection. 
TABLE 8

EFFECT OF SODIUM NITRITE ON THE METABOLISM OF HEXOBARBITAL BY MOUSE IIVER $9,000 \times$ G SUPERNATANT

\begin{tabular}{lcc}
\hline $\begin{array}{l}\text { Additions to } \\
\text { incubation mixture }\end{array}$ & $\begin{array}{r}\text { MM Hexobarbital } \\
\text { metabolized/g liver/30 min } \\
\text { mean } \pm S . E .(N)\end{array}$ & $\mathrm{P}^{1}$ \\
\hline None & $1.28 \pm 0.02(6)$ & - \\
Sodium Nitrite & $1.58 \pm 0.07(6)$ & $>0.01$ \\
$4.52 \times 10^{-5} \mathrm{M}$ & $1.27 \pm 0.03(6)$ & $>0.05$ \\
$9.05 \times 10^{-5} \mathrm{M}$ & $1.24 \pm 0.02(6)$ & $>0.05$ \\
\hline $18.10 \times 10^{-5} \mathrm{M}$ & &
\end{tabular}

1Control vs, sodium nitrite.

2 ug/g liver equivalent sodium nitrite added to incubation media are as follows: $4.52 \times 10^{-5} \mathrm{M}(50 \mathrm{ug} / \mathrm{g}) ; 9.05 \times 10^{-5} \mathrm{M}$ $(100 \mathrm{ug} / \mathrm{g})$ and $18.10 \times 10^{-5} \mathrm{M}(200 \mathrm{ug} / \mathrm{g})$. 
that seen in control mice receiving distilled water. Methylene blue administered $30 \mathrm{~min}$ prior to sodium nitrite effectively reduced subsequent methemoglobin levels, the extent of reduction being proportional to the dose of methylene blue (Table 9).

Sodium nitrite or methylene blue markedly potentiated (80\%) hexobarbital narcosis in mice. However, injection of methylene blue prior to sodium nitrite resulted in potentiation of the hexobarbital effect equal to that seen with either drug alone (Table 10). Duration of barbital narcosis was markedly increased by methylene blue in the absence of sodium nitrite (Table 11).

Effect of Hypobaric Hypoxia and Sodium Nitrite on Brain and Plasma levels of Barbital CI4

The onset of barbital narcosis was significantly reduced in mice exposed to hypobaric hypoxia or injected with sodium nitrite (Table 12). However, sodium nitrite markedly reduced the concentration of barbital $c^{14}$ in brain when the labelled drug was administered intraperitoneally with a depressant dose $(300 \mathrm{mg} / \mathrm{kg})$ of unlabelled barbital. In addition, plasma levels of barbital $\mathrm{c}^{14}$ were lower in the nitrite-treated animals $10 \mathrm{~min}$ after intraperitoneal injection of the labelled isotope. Administration of barbital $\mathrm{C}^{14}$ without a depressant dose of barbital also decreased the penetration of barbital $c^{14}$ into brain, but plasma levels did not differ significantly from control animals. Exposure of mice to hypobaric hypoxia 


\section{TABLE 9}

EFFECT OF METHYIENE BLUE ON NITRITE-INDUCED METHEMOGLOBINEMIA

\begin{tabular}{|c|c|c|}
\hline Drug & $\begin{array}{l}\text { Dose } \\
(\mathrm{mg} / \mathrm{kg})\end{array}$ & $\begin{array}{c}\text { Methemoglobinemia }(\%) \\
\text { mean } \pm \text { S.E. (N) }\end{array}$ \\
\hline Distilled Water ${ }^{1}$ & - & $3.4 \pm 0.57$ \\
\hline Sodium Nitrite ${ }^{2}$ & 100 & $36.1 \pm 1.80^{a}(8)$ \\
\hline $\begin{array}{l}\text { Sodium Nitrite } 3^{+} \\
\text {Methylene Blue }\end{array}$ & $\begin{array}{r}100 \\
25\end{array}$ & $13.0 \pm 2.80^{b}(8)$ \\
\hline $\begin{array}{l}\text { Sodium Nitrite } \\
\text { Methylene Blue }\end{array}$ & $\begin{array}{r}100 \\
50\end{array}$ & $8.7 \pm 1.20^{b}(8)$ \\
\hline
\end{tabular}

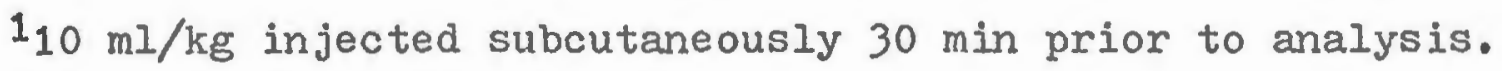
2 Injected subcutaneously $30 \mathrm{~min}$ prior to analysis. 3 Injected intraperitoneally $20 \mathrm{~min}$ prior to sodium nitrite.

aSignificantly greater $(p<0.001)$ than distilled water controls.

bSignificantly less $(p<0.01)$ than sodium nitrite-treated mice. 
TABLE 10

EFFECT OF METHYLENE BLUE ON NITRITE-INDUCED POTENTIATION OF HEXOBARBITAL NARCOSIS

\begin{tabular}{|c|c|c|c|c|}
\hline Treatment & $\begin{array}{r}\text { Dose } \\
\mathrm{mg} / \mathrm{kg}\end{array}$ & $\begin{array}{l}\text { Hexobarbi } \\
\frac{\min \pm}{\text { Controle }}\end{array}$ & $\begin{array}{l}a 1^{1} \text { Narcosis } \\
\frac{\text { Treated }}{\text { Tr }}\end{array}$ & $P$ \\
\hline Sodium Nitrite ${ }^{3}$ & 100 & $38 \pm 3.0(8)$ & $70 \pm 1.8$ (8) & $<0.001$ \\
\hline Methylene Blue 4 & 25 & $58 \pm 2.7(8)$ & $104 \pm 6.4(8)$ & $<0.001$ \\
\hline Methylene Blue 4 & 50 & $46 \pm 6.0$ (9) & $81 \pm 6.0 \quad(8)$ & $<0.001$ \\
\hline $\begin{array}{l}\text { Sodium Nitrite }{ }^{+} \\
\text {Methylene Blue }\end{array}$ & $\begin{array}{r}100 \\
25\end{array}$ & $49 \pm 4.9(7)$ & $89 \pm 7.0$ (8) & $<0.001$ \\
\hline $\begin{array}{l}\text { Sodium Nitrite } \\
\text { Methylene Blue } 5^{+}\end{array}$ & $\begin{array}{r}100 \\
50\end{array}$ & $42 \pm 3.4(7)$ & $88 \pm 7.0 \quad(7)$ & $<0.001$ \\
\hline
\end{tabular}

$1_{120} \mathrm{mg} / \mathrm{kg}$ injected intraperitoneally.

$210 \mathrm{ml} / \mathrm{kg}$ injected subcutaneously or intraperitoneally as required 30 or $50 \mathrm{~min}$ prior to hexobarbital.

3 Injected subcutaneously $30 \mathrm{~min}$ prior to hexobarbital. ${ }^{4}$ Injected intraperitoneally $50 \mathrm{~min}$ prior to hexobarbital. 5 Injected intraperitoneally $20 \mathrm{~min}$ prior to sodium nitrite. 
TABLE 11

ONSET AND DURATION OF BARBITAI NARCOSIS IN MICE TREATED WITH METHYIENE BLUE

\begin{tabular}{|c|c|c|c|}
\hline $\begin{array}{l}\text { Barbital }{ }^{1} \\
\text { Narcosis }\end{array}$ & $\begin{array}{l}\text { Time inte } \\
\text { mean } \pm\end{array}$ & $\frac{\left(\begin{array}{l}\min ) \\
(N)\end{array}\right.}{\text { Treated } 3}$ & \\
\hline Onset & $32 \pm 2.0$ (9) & $15 \pm 1.5(10)$ & $<0,0005$ \\
\hline Duration & $142 \pm 8.8$ & $>282$ & \\
\hline
\end{tabular}

$1300 \mathrm{mg} / \mathrm{kg}$ injected intraperitoneally.

$2_{\text {Distilled water }}(10 \mathrm{ml} / \mathrm{kg})$ injected intraperitoneally 50 min prior to barbital.

$350 \mathrm{mg} / \mathrm{kg}$ injected intraperitoneally $50 \mathrm{~min}$ prior to barbital. 
TABLE 12

EFFECT OF HYPOBARIC HYPOXIA AND SODIUM NITRITE ON THE - INDUCTION OF BARBITAL NARCOSIS

\begin{tabular}{|c|c|c|}
\hline Group & $\begin{array}{l}\text { Barbital }{ }^{1} \text { Narcosis, Onset } \\
\frac{\min \pm \text { S.E. (N) }}{\text { Controll }}\end{array}$ & \\
\hline Sodium Nitrite ${ }^{3}$ & $24 \pm 1.9(8)$ & $<0.025$ \\
\hline Hypobaric Hypoxia ${ }^{4}$ & $16 \pm 1.9(7)$ & $<0.05$ \\
\hline \multicolumn{3}{|c|}{ 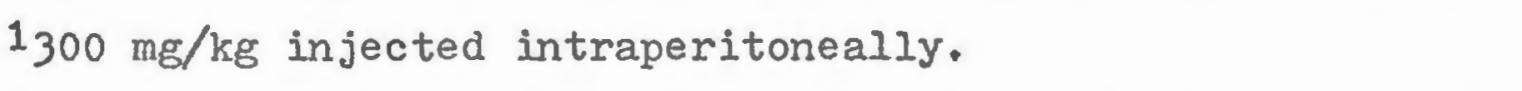 } \\
\hline \multicolumn{3}{|c|}{$\begin{array}{l}\text { 2Mice received distilled water }(10 \mathrm{ml} / \mathrm{kg} \text { ) subcutaneously } 30 \\
\text { min prior to barbital (sodium nitrite experiment) or were } \\
\text { injected with the barbiturate and kept in hypobaric cham- } \\
\text { bers (hypoxia experiment) at room atmosphere (760 mm } \mathrm{Hg} \text {, } \\
\left.21 \% \mathrm{O}_{2}\right) \text {. }\end{array}$} \\
\hline \multicolumn{3}{|c|}{$3100 \mathrm{mg} / \mathrm{kg}$ injected subcutaneously $30 \mathrm{~min}$ prior to barbital. } \\
\hline
\end{tabular}


(364 $\mathrm{mm} \mathrm{Hg}, 10 \% \mathrm{O}_{2}$ ) for $2 \mathrm{~h}$ reduced the absorption of a subsequent intraperitoneal dose of barbital $\mathrm{c}^{14}$. In addition, brain levels of the labelled barbiturate were lower in the hypoxic animals $10 \mathrm{~min}$ after injection (Table 13A,B). Brain and plasma levels were higher in mice administered the labelled compound intraperitoneally with a depressant dose of barbital at room atmosphere, and then exposed for $6 \mathrm{~h}$ to hypobaric hypoxia (Table 13C). Exposure to hypobaric hypoxia (2 hours) or injection of sodium nitrite ( $30 \mathrm{~min}$ pretreatment) did not alter penetration of barbital $\mathrm{C}^{14}$ into brain measured 5 min after intravenous administration of the labelled compound (Table 14).

Effect of Social Deprivation on Drug-Induced Narcosis

Data summarized in Table 15 show that duration of narcosis of the depressant drugs was markedly reduced by chronic isolation of male mice. The magnitude of reduction differed from drug to drug. It was largest in the case of hexobarbital, followed in decreasing order by pentobarbital, chloral hydrate and barbital. With the doses used, the sleeping time of hexobarbital equaled that of barbital in the grouped mice $(p>0.05)$. However, it was considerably less than barbital sleeping time $(p<0.01)$ in the isolated mice. The onset of barbital narcosis was not affected (Table 16). 
TABLE 13A

EFFECT OF SODIUM NITRITE AND BARBITAI ON BRAIN AND PLASMA LEVELS OF BARBITAL $\mathrm{C}^{14}$

\begin{tabular}{|c|c|c|c|c|}
\hline & 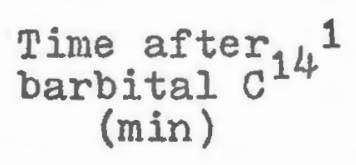 & $\frac{\text { Mean } \pm s}{\text { Controle }}$ & $\frac{\text { E. }(\mathrm{N})}{\text { Treated } 3}$ & $P$ \\
\hline \multirow{2}{*}{$\begin{array}{l}\text { Brain } \\
\mathrm{Dpm} / \mathrm{g}\end{array}$} & 10 & $1694 \pm 225(6)$ & $744 \pm 160(6)$ & $<0.01$ \\
\hline & 30 & $2796 \pm 62 \quad(6)$ & $1969 \pm 285(5)$ & $<0.05$ \\
\hline \multirow{2}{*}{$\begin{array}{l}\text { Plasma } \\
\mathrm{Dpm} / \mathrm{mI}\end{array}$} & 10 & $4263 \pm 606(6)$ & $1914 \pm 262(6)$ & $<0.01$ \\
\hline & 30 & $4172 \pm 147 \quad(6)$ & $3673 \pm 420(6)$ & $>0.05$ \\
\hline \multirow{2}{*}{$\frac{\text { Brain }}{4}$} & 10 & $0.474 \pm 0.12(6)$ & $0.372 \pm 0.04 \quad(6)$ & $>0.05$ \\
\hline & 30 & $0.676 \pm 0.03(6)$ & $0.543 \pm 0.04(5)$ & $<0.05$ \\
\hline
\end{tabular}

$1_{\text {Barbital }} \mathrm{C}^{14}(2.0 \mathrm{uc} / \mathrm{kg})$ injected intraperitoneally in a solution containing $3 \%$ unlabelled barbital $(300 \mathrm{mg} / \mathrm{kg})$.

${ }^{2}$ Distilled water $(10 \mathrm{ml} / \mathrm{kg})$ injected subcutaneously $30 \mathrm{~min}$ prior to barbital.

3 Sodium nitrite $(100 \mathrm{mg} / \mathrm{kg})$ injected subcutaneously $30 \mathrm{~min}$ prior to barbital.

$\frac{4 \mathrm{ppm} / \mathrm{g} \text { brain }}{\mathrm{Dpm} / \mathrm{mI} \text { plasma }}$ 
TABLE 13B

EFFECT OF SODIUM NITRITE OR HYPOBARIC HYPOXIA ON BRAIN AND PLASMA LEVELS OF BARBITAL $\mathrm{C}^{14}$

\begin{tabular}{|c|c|c|c|c|}
\hline & $\begin{array}{l}\text { Time after } \\
\text { barbital } \mathrm{C}^{14} \\
\qquad(\mathrm{~min})\end{array}$ & \multicolumn{2}{|c|}{$1 \quad$ Mean \pm S.E. (N) } & \\
\hline \multirow{3}{*}{$\begin{array}{l}\text { Brain } \\
\mathrm{Dpm} / \mathrm{g}\end{array}$} & \multicolumn{4}{|c|}{ Sodium Nitrite 3} \\
\hline & 10 & $1992_{-203}^{+}(6)$ & $1457 \pm 108(6)$ & $<0.05$ \\
\hline & 30 & $2162 \pm 160 \quad(5)$ & $1818_{-141 （ 6)}$ & $>0.05$ \\
\hline \multirow{2}{*}{$\begin{array}{l}\text { Plasma } \\
\mathrm{Dpm} / \mathrm{ml}\end{array}$} & 10 & $4452 \pm 342(6)$ & $4934 \pm 392(6)$ & $>0.05$ \\
\hline & 30 & $4167 \pm 191 \quad(5)$ & $4559 \pm 108 \quad(6)$ & $>0.05$ \\
\hline \multirow{3}{*}{$\frac{\text { Brain }}{4}$} & 10 & $0.445 \pm 0.03(6)$ & $0.299 \pm 0.02 \quad(6)$ & $<0.01$ \\
\hline & 30 & $0.481 \pm 0.05 \quad(5)$ & $0.399 \pm 0.03 \quad(6)$ & $>0.05$ \\
\hline & \multicolumn{4}{|c|}{ Hypobaric Hypoxia 5} \\
\hline $\begin{array}{l}\text { Brain } \\
\mathrm{Dpm} / \mathrm{g}\end{array}$ & 10 & $2063 \pm 154(6)$ & $1141 \pm 188(6)$ & $<0.01$ \\
\hline $\begin{array}{l}\text { Plasma } \\
\mathrm{Dpm} / \mathrm{ml}\end{array}$ & 10 & $5321 \pm 85 \quad(6)$ & $4282 \pm 402(6)$ & $<0.05$ \\
\hline$\frac{\text { Brain }}{\text { Plasma }}$ & 10 & $0.389 \pm 0.03(6)$ & $0.285 \pm 0.06(6)$ & $<0.05$ \\
\hline
\end{tabular}

$1_{2} .0 \mathrm{uc} / \mathrm{kg}$ injected intraperitoneally.

2 Sodium nitrite-Dist. water $(10 \mathrm{ml} / \mathrm{kg}$, subcut.) $30 \mathrm{~min}$ prior to barbital C14; Hypobaric-Mice kept under room air after barbital $\mathrm{c}^{14}$ injection.

$3100 \mathrm{mg} / \mathrm{kg}$ injected subcutaneously $30 \mathrm{~min}$ prior to barbital $\mathrm{c}^{14}$.

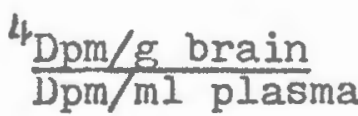

$5 \mathrm{Mice}$ exposed to $364 \mathrm{~mm} \mathrm{Hg}\left(10 \% \mathrm{O}_{2}\right)$ for $2 \mathrm{~h}$ prior to barbital 
TABLE $13 \mathrm{C}$

EFFECT OF HYPOBARIC HYPOXIA AND BARBITAL ON BRAIN AND PLASMA IEVELS OF BARBITAL $C^{14} 6$ HOURS AFTER INJECTION

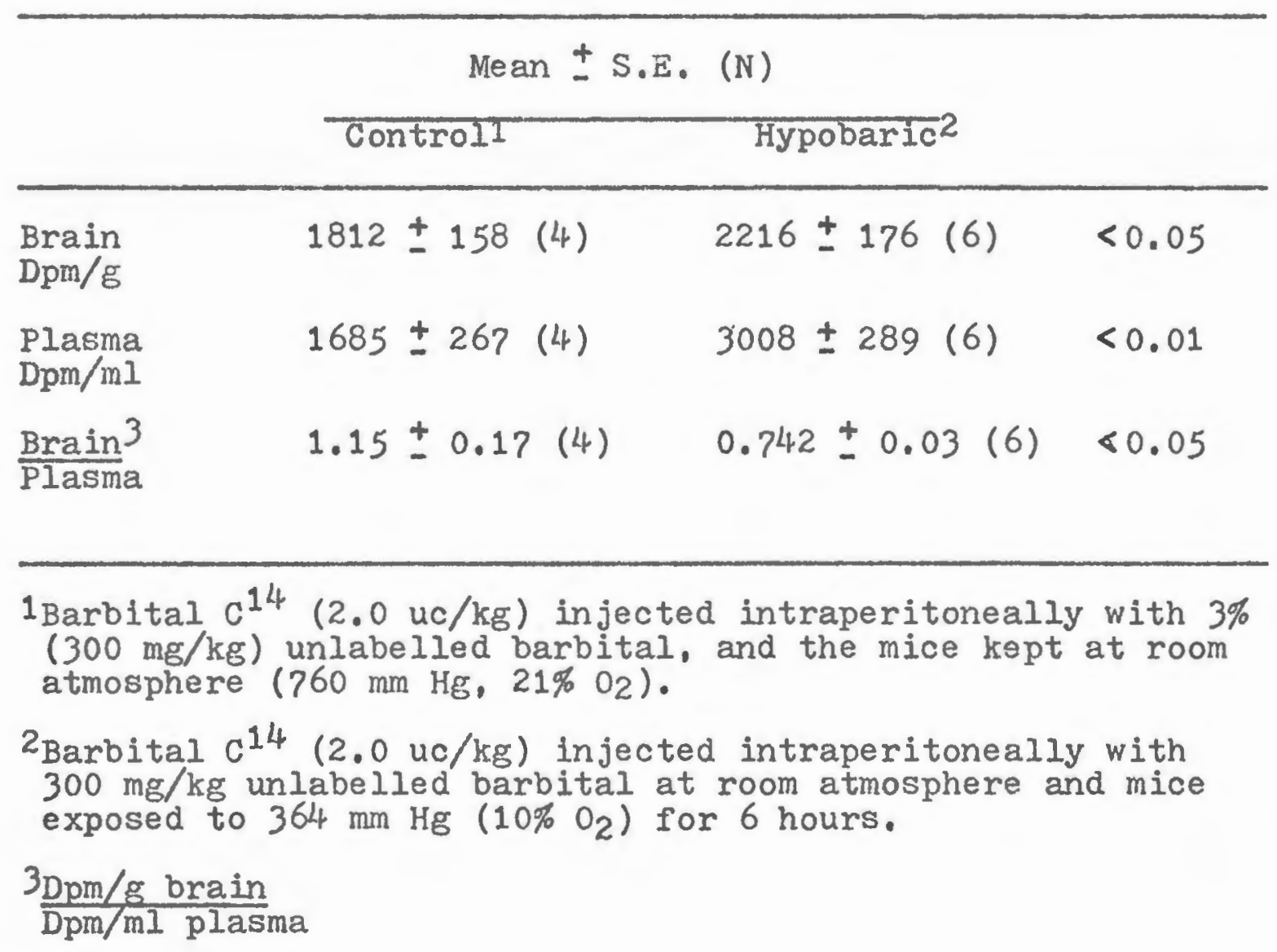


TABLE 14

EFFECT OF SODIUM NITRITE OR HYPOBARIC HYPOXIA ON THE PENETRATION OF INTRAVENOUS BARBITAL $\mathrm{C}^{14}$ INTO BRAIN

\begin{tabular}{|c|c|c|c|}
\hline \multicolumn{3}{|c|}{ Mean \pm S.E. $(N)$} & \multirow[t]{2}{*}{$\mathrm{P}$} \\
\hline & Controll & Treated 2 & \\
\hline \multicolumn{4}{|c|}{ Sodium Nitrite } \\
\hline $\begin{array}{l}\text { Brain } 3 \\
\mathrm{Dpm} / \mathrm{g}\end{array}$ & $1670 \pm 275(5)$ & $1555 \pm 220(5)$ & $>0.05$ \\
\hline $\begin{array}{l}\mathrm{Plasma} \\
\mathrm{Dpm} / \mathrm{ml}\end{array}$ & $4402 \pm 391(5)$ & $5315 \pm 325(5)$ & $>0.05$ \\
\hline$\frac{\text { Brain }^{4}}{\text { Plasma }}$ & $0.306 \pm 0.04 \quad(5)$ & $0.364 \pm 0.05(5)$ & $>0.05$ \\
\hline \multicolumn{4}{|c|}{ Hypobaric Hypoxia } \\
\hline $\begin{array}{l}\text { Brain } \\
\mathrm{Dpm} / \mathrm{g}\end{array}$ & $1555 \pm 220$ & $1498 \pm 353(5)$ & $>0.05$ \\
\hline $\begin{array}{l}\text { Plasma } \\
\mathrm{Dpm} / \mathrm{ml}\end{array}$ & $4401 \pm 391(5)$ & $5639 \pm 803(6)$ & $>0.05$ \\
\hline$\frac{\text { Brain }}{\text { Plasma }}$ & $0.362 \pm 0.04(5)$ & $0.271 \pm 0.05(5)$ & $>0.05$ \\
\hline \multicolumn{4}{|c|}{$\begin{array}{l}{ }^{1} \text { Mice injected subcutaneously with } 10 \mathrm{ml} / \mathrm{kg} \text { distilled water } \\
\text { ( } 30 \mathrm{~min} \text { pretreatment) prior to intravenous barbital } \mathrm{c}^{14}(2 . \mathrm{c} \\
\mathrm{uc} / \mathrm{kg} \text { ) or maintained in the hypobaric chambers under room } \\
\text { air and administered the labelled compound. }\end{array}$} \\
\hline \multicolumn{4}{|c|}{$\begin{array}{l}{ }^{2} \text { Mice administered sodium nitrite }(100 \mathrm{mg} / \mathrm{kg} \text { subcut., } 30 \mathrm{~min} \\
\text { pretreatment) or exposed to hypobarif hypoxia }(364 \mathrm{~mm} \mathrm{Hg}) \\
\text { for } 2 \mathrm{~h} \text { and injected with barbital } \mathrm{C} 14 \text {. }\end{array}$} \\
\hline \multicolumn{4}{|c|}{3 Measured 5 min after intravenous barbital $\mathrm{c}^{14}$. } \\
\hline$\frac{{ }^{4} \mathrm{Dpm} / \mathrm{g} \mathrm{b}}{\mathrm{Dpm} / \mathrm{mI}}$ & & & \\
\hline
\end{tabular}


TABIE 15

EFFECT OF PROLONGED SOCIAL ISOLATION ON DRUG-INDUCED NARCOSIS IN MICE

\begin{tabular}{lrrrrr}
\hline \multicolumn{1}{c}{ Drug } & \multicolumn{1}{c}{$\begin{array}{c}\text { Nose } \\
(\mathrm{mg} / \mathrm{kg})\end{array}$} & Grouped & Isolated & \\
\hline Hexobarbital & 120 & $98 \pm 3.5(9)$ & $54 \pm 1.4(10)$ & $<0.0005$ \\
Pentobarbital & 50 & $60 \pm 4.7(15)$ & $39 \pm 3.3(17)$ & $<0.0005$ \\
Chloral Hydrate & 350 & $76 \pm 4.2(18)$ & $57 \pm 3.9(15)$ & $<0.005$ \\
Barbital & 300 & $107 \pm 5.7(17)$ & $87 \pm 8.8(18)$ & $<0.05$ \\
\hline
\end{tabular}

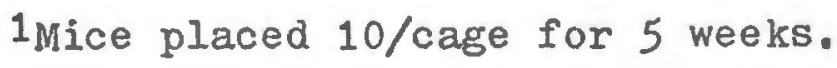
${ }^{2}$ Mice placed 1/cage for 5 weeks. 
TABLE 16

ONSET OP BARBITAL NARCOSIS IN CHRONICALLY ISOLATED AND GROUPED MICE

\begin{tabular}{lccc}
\hline $\begin{array}{l}\text { Experimental } \\
\text { Condition }\end{array}$ & $\mathrm{N}$ & $\begin{array}{l}\text { Barbital Narcosis } \\
\text { Onset, min } \pm \mathrm{S.E.}\end{array}$ & $\mathrm{P}$ \\
\hline Grouped & 17 & $26 \pm 1.3$ & \\
Isolated & 18 & $26 \pm 1.3$ & $>0.05$ \\
\hline
\end{tabular}

$1300 \mathrm{mg} / \mathrm{kg}$ injected intraperitonealiy. 
Effect of Social Deprivation on Hexobarbital Oxidase Activity

In vitro studies showed that the hepatic microsomal fractions isolated from chronically deprived male mice metabolized hexobarbital at a rate higher than the hepatic fractions isolated from control mice (Table 17). Chronic deprivation also decreased body weight.

Effect of Social Deprivation on Disappearance of Body Hexobarbital and Hexobarbital Concentration at Awakening

Socially deprived mice exhibited a higher concentration of hexobarbital in the body at the time of awakening than did their counterparts which were housed with other mice. In addition, 15 min after drug administration, body concentration of hexobarbital in socially deprived mice was significantly less than in the community housed animals (Table 18). Both males as well as females showed these differences.

Relationship of Pharmacological Alterations to IsolationInduced Aggression

Gradually, following social deprivation, initially non-aggressive males developed aggressive behavior which was manifested in intense fighting when they were paired in a strange cage. After one week of social deprivation, only $20 \%$ of the males engaged in fighting while 5 weeks of deprivation resulted in most of the males becoming aggressive (Figure 12). Female mice tested after 5 weeks of social deprivation did not exhibit aggressiveness. Hexobarbital narcosis was maximally reduced after one week 
TABLE 17

EFFECT OF SOCIAL ISOLATION AND GROUPING ON BODY WEIGHT AND HEXOBARBITAL OXIDASE ACTIVITY IN MICE

\begin{tabular}{|c|c|c|c|}
\hline & $\frac{\text { Mean } \pm}{\text { GroupedI }}$ & $\frac{\text { S.E. }(N)}{\text { Isolatedz }}$ & $P$ \\
\hline $\begin{array}{l}\text { uM Hexobarbital } \\
\text { metabolized } / \mathrm{g} / 30 \mathrm{~min}\end{array}$ & $0.628 \pm 0.08 \quad(9)$ & $1.07 \pm 0.08(10)$ & $<0.001$ \\
\hline Body weight & $37.670 \pm 1.10$ (9) & $34.00 \pm 0.70(10)$ & $<0.005$ \\
\hline $\begin{array}{l}\text { Liver we ight } \\
\% \text { of body weight }\end{array}$ & $4.740 \pm 0.08 \quad(9)$ & $5.19 \pm 0.10$ (1) & $<0.005$ \\
\hline
\end{tabular}

1 Mice grouped 10/cage for 5 weeks.

2 Mice placed $1 /$ cage for 5 weeks. 
TABLE 18

EFFECT OF SOCIAL ISOLATION ON HEXOBARBITAL METABOLISM AND HEXOBARBITAL CONCENTRATION AT AWAKENING

\begin{tabular}{|c|c|c|c|}
\hline Sex & \multicolumn{2}{|c|}{$\begin{array}{l}\text { muM Hexobarbital/g body wt. } \\
\text { mean } \pm \text { S.E. (N) }\end{array}$} & \\
\hline \multicolumn{4}{|c|}{15 min after injection ${ }^{3}$} \\
\hline Male & $341 \pm 13(8)$ & $299 \pm 17(6)$ & $<0.05$ \\
\hline Female & $441 \pm 23(8)$ & $363 \pm 17(8)$ & $<0.01$ \\
\hline \multicolumn{4}{|c|}{ At Awakening } \\
\hline Male & $170 \pm 14(8)$ & $214 \pm 8.7(10)$ & $<0.01$ \\
\hline Female & $221 \pm 17(8)$ & $277 \pm 23(9)$ & $<0.05$ \\
\hline
\end{tabular}




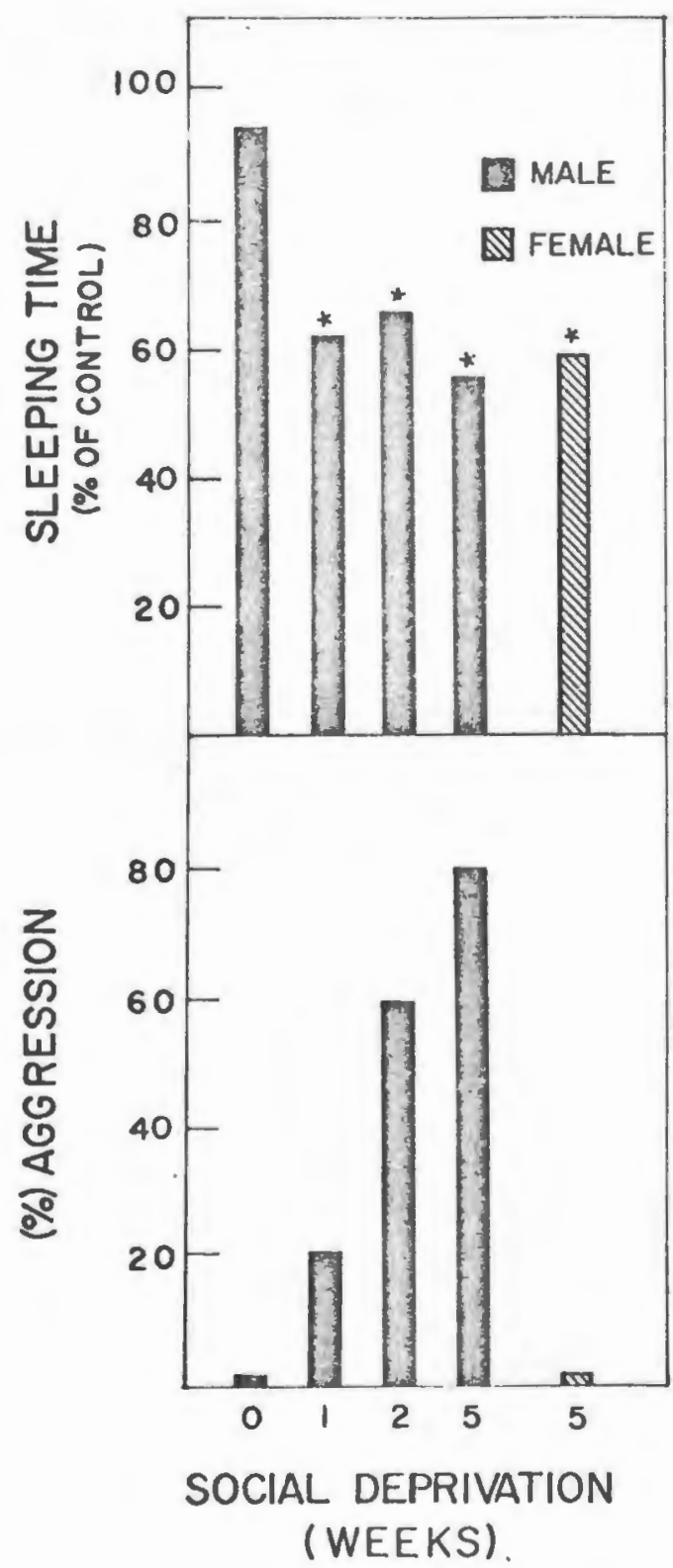

Figure 12. FIGHTING RESPONSES (AGGRESSION) AND HEXOBARBITAL (120 mg/kg, intraperitoneally) NARCOSIS IN MICE SUBJECTED TO SOCIAL DEPRIVATION, EXPRESSED AS \% OF CONTROL VALUES OBTAINED FROM MICE HOUSED IN GROUPS OF 10. (*) Significantly less $(p<0.05)$ than mean narcosis-time of grouped controls. 
of social deprivation. Whereas fighting behavior progressively increased through succeeding weeks of isolation, the decline in barbiturate narcosis was unaltered during that period. The females, although not aggressive at 5 weeks of isolation, still exhibited a reduction in barbiturate narcosis to the same degree as the males which were aggressive (Figure 12).

Effect of Modified Endocrine Function on Isolation-Induced Pharmacologic Alterations and Aggression

The aggressive behavior and reduction in hexobarbital narcosis induced by social deprivation was not altered by adrenalectomy (Table 19). However, both the altered response to hexobarbital and the aggressiveness was absent in the mice castrated prior to social deprivation.

Effect of Social Deprivation on Shock Avoidance Behavior Latency to avoidance of paw shock was significantly lower $(p=0.04)$ in the socially deprived mice (Figure 13). In addition, chronically deprived animals were more resistant to the decrement in avoidance produced by chlorpromazine than community-housed mice (Table 20). 
TABLE 19

EFFECT OF ENDOCRINE MODIFICATION ON ISOLATION-INDUCED

AGGRESSION AND DECREASE IN HEXOBARBITAL NARCOSIS

\begin{tabular}{|c|c|c|c|c|}
\hline Treatment & Fighting $_{(\%)}^{4}$ & $\frac{\operatorname{mean}^{\operatorname{Narc}}}{\text { Grouped }}$ & $\begin{array}{l}\operatorname{osis}^{1} \\
\frac{\text { S.E. (N) }}{\text { Isolated }}\end{array}$ & $P$ \\
\hline Intact & 100 & $45 \pm 4.0 \quad(5)$ & $33 \pm 2.0 \quad(6)$ & $<0.025$ \\
\hline Sham operated & 100 & $55 \pm 5.6(9)$ & $26 \pm 2.0 \quad(6)$ & $<0.005$ \\
\hline Adrenalectomized & 100 & $51 \pm 4.5(7)$ & $33 \pm 2.8 \quad(7)$ & $<0.005$ \\
\hline Gonadectomized & 0 & $46 \pm 3.9(13)$ & $41 \pm 4.0$ (13) & $>0.05$ \\
\hline
\end{tabular}

$1120 \mathrm{mg} / \mathrm{kg}$ hexobarbital injected intraperitoneally. 2 Mice placed 10/cage for 5 weeks. 3 Mice placed 1/cage for 5 weeks. ${ }^{4}$ Four pairs of mice placed in strange cages for $15 \mathrm{~min}$. 


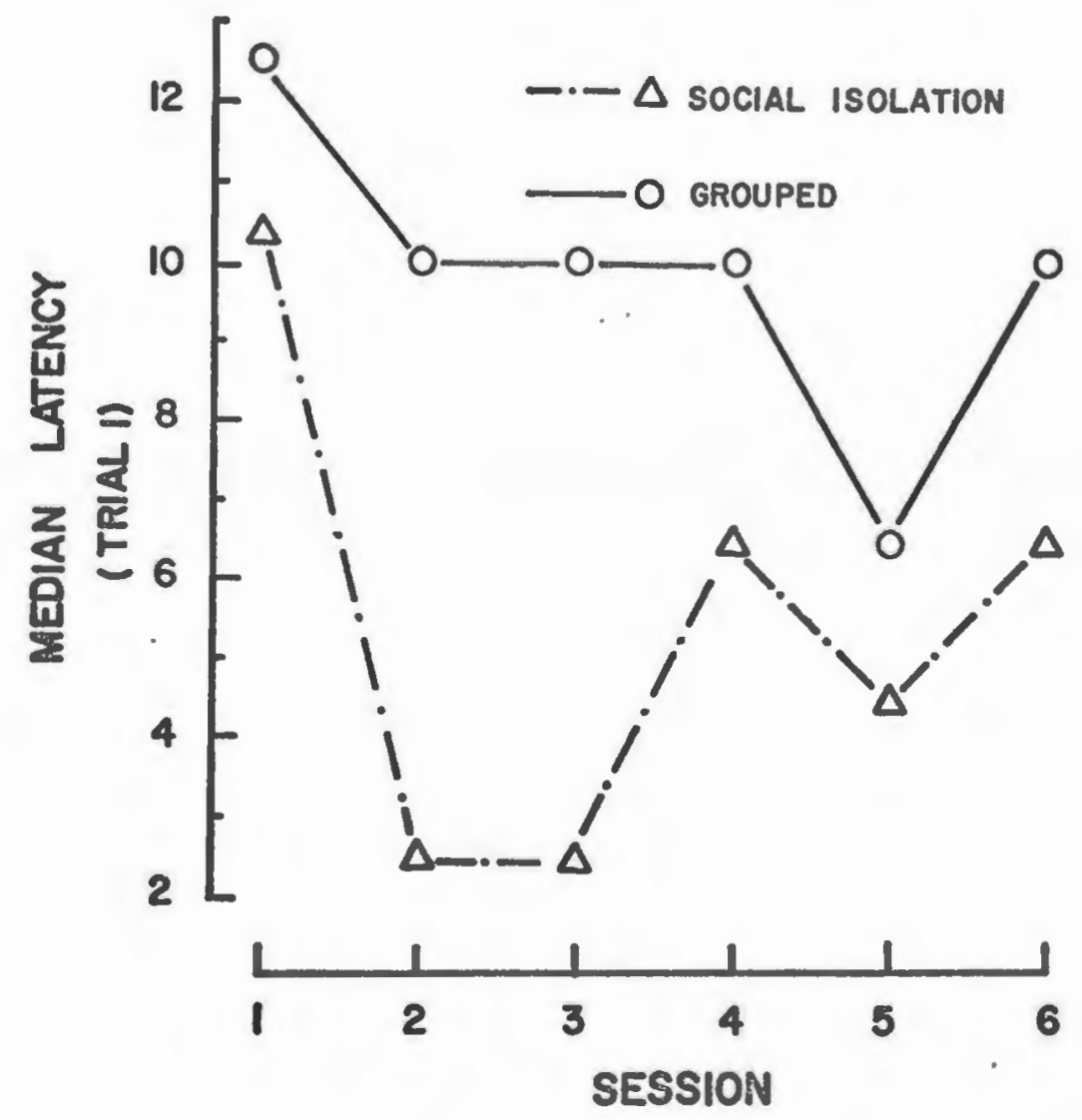

Figure 13. MEDIAN LATENCY (SEC) TO AVOIDANCE OF ELECTRIC SHOCK IN ISOLATED AND GROUPED MICE. Each point represents 10 animals. 
TABLE 20

EFFECT OF CHLORPROMAZINE ON CONDITIONED AVOIDANCE BEHAVIOR IN GROUPED AND ISOLATED MICE

\begin{tabular}{lccc}
\hline \multirow{2}{*}{ Treatment } & \multicolumn{2}{c}{ Avoidance $\%^{1}$} & $P$ \\
\cline { 2 - 3 } No Drug & 90 & 90 & $>0.05$ \\
$\frac{\text { Chlorpromazine }}{2 \mathrm{mg} / \mathrm{kg}}$ & 50 & 60 & $>0.05$ \\
$5 \mathrm{mg} / \mathrm{kg}$ & 0 & 40 & $<0.05$ \\
\hline
\end{tabular}

$1_{\text {No }}$ drug-avoidance on 5 th consecutive trial morning of test day. Chlorpromazine-Avoidance based on one trial $30 \mathrm{~min}$ after drug administration on afternoon of test day. Each group represents \% avoiding out of 20 (No Drug) or 10 (Chlorpromazine) mice.

2 In jected intraperitoneally. 


\section{v. DISCUSSION}

\section{Acute Hypoxia}

The ability of rats to resist the convulsive effects of hyperbaric oxygen (Wood et al., 1967) and the lethal effects of hypoxia (Wood et al., 1968) suggested that these animals may provide a useful tool for research into protective mechanisms against alterations in drug action induced by hypobaric environments. Data obtained in this investigation indicate that rats exposed to hypobaric hypoxia are less sensitive than mice to potentiation of CNS depressants (Table 1) and hypothermia (Figure 2) induced by the low oxygen environment. Since alteration in body temperature affects CNS depressant activity (Borzelleca and Manthei, 1957; Fuhrman, 1947; Setnikar and Temelcou, 1962) these findings suggest that the lowered susceptibility of rats as compared with mice to potentiation of drug-induced narcosis during hypoxia may in part be related to the lower degree of hypothermia exhibited by rats exposed to hypobaric conditions. Based on this hypothesis, since CNS depressants interact with thermoregulatory mechanisms and reduce body temperature (Setnikar and Temelcou, 1962), hypoxia may be expected to potentiate this effect and thus enhance CNS depression. Hypobaric hypoxia was observed to potentiate drug-induced 
hypothermia in mice in all cases (Figure $3-5$ ), the most extensive change being observed during barbital narcosis where body temperature was seen to reach ambient temperature $\left(22^{\circ} \mathrm{C}\right)$ under hypoxia. Prevention of hypoxiainduced hypothermia at $30^{\circ} \mathrm{C}$ ambient temperature slightly enhanced the pentobarbital action, only moderately reduced chloral hydrate action, but greatly reduced the barbital effect (Table 3). It would appear then that hypothermia during hypoxia has a profound effect on the response to barbital, but little or no effect with respect to the other depressants. This may be related to the fact that reduction in body temperature under hypoxia was considerably more during barbital narcosis than with the other depressants.

The similar results obtained with exposure to low oxygen at normal atmospheric pressure or to room air at reduced pressure (Table 2) suggest that potentiation of barbiturate narcosis and associated effects are due primarily to a deficiency in ambient oxygen.

Exposure to hyperbaric oxygen causes marked reduction of brain -aminobutyric acid (GABA) (Wood et al., 1967) a proposed inhibitory transmitter (Benett et al., 1963) and also produces convulsions in mice (Faiman and Hable, 1966). In contrast, exposure to hypoxia increases brain levels of this amine (Wood et al., 1968). In the present experiment acute exposure to hypobaric hypoxia antagonized convulsions produced by semicarbazide, me- 
thionine sulphoximine or m-fluorotyrosine (Figures 7-9). Semicarbazide and methionine sulphoximine decrease the symthesis of brain GABA (Killam and Bain, 1967; Roberts and Frankel, 1951; Lamar and Sellinger, 1965) while mfluorotyrosine produces blockace of the citric acid cycle by conversion to fluoroacetate (Weissman and Koe, 1967). Since breathing of hypoxic air can lead to impairment of brain oxidative metabolism (Gurdjian et al., 1949) with possible reduction in the use of GABA in the shunt pathway of the citric acid cycle (Wood, 1967), depletion of GABA by semicarbazide or methionine sulphoximine may be compensated for during hypoxia resulting in an anticonvulsant effect. In addition, increased dependence of brain neurons on anerobic metabolism during hypoxia may reduce the consequences of impairing aerobic metabolism by fluoroacetate, thus reducing seizures due to $m$-fluorotyrosine. These observations suggest an alteration in brain excitability during hypoxia.

The slower decline in pentobarbital body levels (Table 4) suggests that acute exposure of mice to hypoxia depresses in vivo drug metabolism. This may be due to the dependence of hepatic drug metabolism on molecular oxygen (Gillete et al., 1957). In addition, hypothermia during hypoxia may depress drug metabolism in hepatic microsomes (Leadbeater and Davies, 1964; Setnikar and Temelcou, 1962; Kalser et al., 1968). An inability to gain righting reflex under hypoxia 
at otherwise inadequate concentration of pentobarbital (Table 4), enhanced narcosis due to barbital, a drug excreted unmetabolized (Dorfman and Goldbaum, 1947; Maynert and Van Dyke, 1950; Ebert et al., 1964), and reduction in drug-induced convulsions would indicate that a decrease in brain excitability has taken place. Since barbiturates depress the oxygen utilization of nervous tissue (Aldridge, 1962) reduced availability of oxygen during hypoxia could facilitate barbiturate action. Reduction in body temperature depresses tissue oxygen utilization (Bering, 1961; Field et al., 1944) and may further enhance the CNS depression. The fact that pentobarbital raises brain levels of GABA (0ja et al., 1968) would suggest that hypoxiainduced elevation of GABA (Wood et al., 1968) could further sensitize the nerve cell to drug-induced depression. The respiratory alkalosis due to hyperventilation during hypoxia (Henderson and Radloff, 1932) could enhance drug binding with plasma or brain proteins (Goldbaum and Smith, 1954) and affect availability of drugs to the site of action and subsequent interaction with receptors. Antagonism by hypoxia of seizures due to semicarbazide administered intracerebrally (Figure 10), a method of injection which obviates peripheral factors affecting drug action, supports the hypothesis that hypoxia alters brain sensitivity by a direct effect on brain metabolism. However, the specific biochemical changes related to altered neuronal excitability during hypoxia remain to be deter- 
mined.

Sodium nitrite $(100 \mathrm{mg} / \mathrm{kg}$ ) injected subcutaneously potentiates hexobarbital narcosis, increases methemoglobin blood levels and reduces body temperature (Figure 11). The temporal relationship of these 3 parameters suggested that methemoglobin and/or hypothermia may be involved in the enhancement of the barbiturate effect by sodium nitrite. Additional expeximents indicated that hypothermia due to sodium nitrite was important in the response to barbital but not that of hexobarbital in mice (Table 5). This resembles the effects seen with these drugs in mice exposed to hypobaric hypoxia.

Hepatic detoxification was reduced in vivo after administration of sodium nitrite as evidenced by a slower decline of hexobarbital in the body (Table 6). These observations and the fact that sodium nitrite did not inhibit hexobarbital metabolism in vitro (Table 8) suggest that the decreased hepatic metabolism in vivo is a result of hypoxia due to methemoglobinemia produced by rhis arug. Potentiation of barbital narcosis (Table 5), antagonism of intracerebral semicarbazide convulsions (Figure 11) and the ability of nitrite-treated animals to remain asleep at a barbiturate concentration otherwise insufficient to cause narcosis (Table 6) suggest that a decrease in threshold of brain neurons to drug-induced depression has taken place. Since direct intracerebral injection of sodium nitrite did not affect hexobarbital narcosis or 
reduce body temperature (Table 7 ), it is likely that the altered brain excitability and hypothermia is related to methemoglobin-induced hypoxia.

Although methylene blue effectively reduced the methemoglobinemia produced by sodium nitrite (Table 9), it markedly potentiated hexobarbital and barbital narcosis in the absence of nitrite (Tables 10 and 11). Potentiation of hexobarbital action by methylene blue is probably caused by the known inhibitory effect of this drug on microsonal drug metabolism (Gillete et al., 1957). Prolongation of barbital narcosis suggests altered brain sensitivity by methylene blue. Effect of the dye on hepatic and cerebral metabolism may be related to production of a functional hypoxia due to interference with electron transport components of oxidative metanolism. However, the dye may also compete for excretion with barbiturates.

The marked enhancement of barbiturate action, in spite of extensive reduction in methemoglobin by methylene blue, limited the use of this compound to test the role of methemoglobin in the pharmacologic response to sodium nitrite. However, since the combination of methylene blue and sodium nitrite is not symergistic with respect to hexobarbital narcosis $(80 \%$ increase in hexobarbital narcosis alone or in combination-Table 10), one may conclude that a pharmacologic antagonism does in fact exist, and the resultant effect on hexobarbital potency is due solely 
to methylene blue or to a reduced but equal contribution of methylene blue, and sodium nitrite.

The decreased onset to barbital narcosis observed during hypobaric hypoxia or after sodium nitrite may be due to enhanced CNS sensitivity, increased absorption from the site of injection or more rapid penetration into brain. Mice injected with sodium nitrite showed lower brain and plasma levels of barbital $\mathrm{c}^{14}$ administered intraperitoneally with a depressant dose of unlabelled barbital (Table 13A). Exposure to hypobaric hypoxia produced similar results (Table 13B). These data indicate a decreased absorption of the barbiturate from the site of injection. In addition, a decrease in brain/plasma ratio of barbital $\mathrm{c}^{14}$ under these conditions indicates a reduced penetration into brain. Slower absorption after intraperitoneal injection may be a consequence of peripheral vasoconstriction due to hypothermia (Hardy, 1961) produced by these treatments. In fact, a decrease in blood supply to the periphery during hypoxia has been observed (Monge, 1960). The apparent reduced penetration of barbital into brain is most likely due to limited absorption from the periphery since hypobaric hypoxia or sodium nitrite does not alter penetration of barbital $\mathrm{C}^{14}$ into brain at an early time after intravenous injection (Table 14). The slower rate of absorption could prolong body levels of drug and potentiate barbital narcosis. However, a shorter onset to barbital narcosis with 
a concomitant decrease in absorption and brain levels of the barbiturate supports the hypothesis that the threshold of brain neurons to drug-induced depression is lowered in hypoxic conditions.

Brain and plasma levels of barbital $c^{14}$ were higher in mice exposed to hypobaric hypoxia for $6 \mathrm{~h}$ during barbital narcosis than in narcotized mice breathing room atmosphere (Table 13C). Reduction in body temperature decreases kidney function (Andjas, 1956; Moyer et al., 1956) and mice subjected to hypoxia during barbital narcosis show a marked degree of hypothermia (Figure 6). Therefore, the slower decline in brain and plasma levels of barbital $\mathrm{c}^{14}$ is probably due to decreased excretion due to lowered body temperature by this condition. Decreased excretion of the barbiturate may well contribute to the marked potentiation of barbital narcosis observed in hypoxic mice.

\section{Social Isolation}

Socially deprived mice show a reduced response to drug-induced CNS depression (Table 15) with concomitant increase in hepatic drug metabolism in vitro and in vivo (Table 17 and 18). These data suggest that chronic deprivation of social stimuli enhances the activity of hepatic drug-metabolizing enzymes.

Reduced permeability of drugs into the CNS may not be a factor in decreasing narcosis as the onset of 
barbital narcosis was not altered (Table 16). Further, the action of the short-acting barbiturates, hexobarbital and pentobarbital, which was markedly reduced, is not limited by their penetration into the CNS. Antagonism of narcosis due to barbital (Table 15) and failure to maintain loss of righting reflex at adequate concentrations of hexobarbital (Table 16) suggest that chronic deprivation of social stimuli raises arousal levels of mice such that their susceptibility to CNS depressants is reduced. This would predict enhanced effectiveness of CNS stimulants. In fact, chronically isolated mice are hypersensitive to various stimulants (Consolo et al 1965a; Welch and Welch, 1966).

The aggressive behavior developed in male mice after social deprivation may provide an indicator of physiological alterations resulting in altered brain excitability. This would in tum result in altered pharmacologic effects. However, the isolation-induced change in response to barbiturates did not correlate either temporally or otherwise with aggressiveness (Table 12). In addition female mice, although not exhibiting aggressiveness, showed a decreased response to hexobarbital. This suggests that the general increase in neuroexcitability in the socially deprived animals is not directly related to the development of aggressiveness. Consequently, the elevated neuroexcitability and the aggressiveness probably do not have identical biological bases. 
The decreased latency to avoidance of electric shock in isolated mice (Figure 13) suggests an increased sensitivity to physical stimuli. These results support the observations of Kimbrell (1967) and further indicate a state of heightened excitability as suggested by previous data obtained in this investigation. The reduced effectiveness of chlorpromazine in producing a decrement in avoidance in socially deprived mice may be due to the state of heightened arousal. However, a more rapid detoxication of chlorpromazine in isolated mice may also be a contributing factor.

A specific biochemical mechanism for the alteration in barbiturate sensitivity and development of aggressiveness due to prolonged social isolation is not clear at this time. It is probably not due to decreased turnover of brain serotonin, a neurohumor thought to regulate brain excitability (Jouvet, 1969), because lower serotonin turnover is found only in socially deprived males and not in socially deprived females (Giacalone et al., 1968). The fact that gonadectomy but not adrenalectomy prevented isolation-induced pharmacologic alterations and aggressiveness (Table 19) suggests that anabolic steroids, which have been observed to stimulate hepatic drug metabolism (Booth and Gillete, 1962; Novick et al., 1966) may be involved in this response. In fact social deprivation has been suggested as activating the pituitary-gonadal axis (Brain and Lowell, 1969). This would suggest that 
the enhanced hepatic metabolism may be due to an initial hyperactivity of the posterior hypothalamus which is believed to regulate hepatic microsomal enzymes (Nair et al., 1970). The absence of aggressive behavior in male mice castrated prior to social deprivation has been reported previously (Sigg et al., 1966). 


\section{SUMMARY AND CONCLUSIONS}

1. Rats are less susceptible than mice to hypoxia-induced pharmacologic alterations and hypothermia.

2. Potentiation of the activity of CNS depressants by hypobaric hypoxia is due to low oxygen and not reduced barometric pressure.

3. Enhancernent of drug-induced hypothermia during hypoxia is an important factor in potentiation of the barbital effect but not necessarily in alteration of pentobarbital or chloral hydrate depression.

4. Hypoxia antagonized convulsions due to intraperitoneal semicarbazide, methionine sulphoximine or m-fluorotyrosine. In addition, seizures produced by intracerebral semicarbazide were reduced by hypoxia. Body concentration of pentobarbital is lower in mice awakening under hypoxia. These observations suggest decreased brain excitability during hypoxia.

5. Disappearance of body hexobarbital was slower in mice exposed to hypoxia. These data suggest that hypoxia reduces in vivo metabolism of barbiturates.

6. Injection of sodium nitrite potentiates hexobarbital narcosis, raises blood levels of methemoglobin and lowers body temperature.

7. Hypothermia due to sodium nitrite is important in enhancement by the drug of narcosis due to barbital 
but not that of hexobarbital.

8. Decline of hexobarbital in the whole body is slower in nitrite-treated mice than in control animals. Sodium nitrite added in vitro did not inhibit hexobarbital oxidase activity. Intracerebral injection of sodium nitrite did not affect hexobarbital narcosis or reduce body temperature. These data suggest that injection of sodium nitrite reduces hexobarbital metabolism in vivo and that this effect is probably due to hypoxia produced by methemoglobinemia due to this drug.

9. Mice injected with sodium nitrite show lower incidence of convulsions after intracerebral semicarbazide. Body concentration of hexobarbital is lower at awakening in mice treated with sodium nitrite. These observations, in addition to prolongation of barbital narcosis suggests that treatment with sodium nitrite enhances depression of brain neurons.

10. Methylene blue reduced nitrite-induced methemoglobinemia but markedly enhanced hexobarbital and barbital narcosis in the absence of nitrite. The combination of methylene blue and sodiun nitrite resulted in potentiation of hexobarbital narcosis equal to that seen with either drug alone. These findings suggest enhanced central depression with possible reduction in hepatic metabolism of hexobarbital after methylene blue. These data also suggest that a pharmacological antagonism of 
sodium nitrite action may exist due to reduction in nitrite-induced methemoglobinemia by methylene blue.

11. Sodium nitrite or hypobaric hypoxia decreases absorption and penetration of barbital $c^{14}$ into brain after intraperitoneal injection of the labelled drug. These treatments do not affect penetration of intravenous barbital $\mathrm{C}^{14}$ into brain at an early time after injection. These data suggest that reduced rate of drug penetration into brain may be related to limited absorption from the periphery. Further, since onset of barbital narcosis is reduced under these conditions, additional evidence is presented for enhanced central depression during hypoxia.

12. Brain and plasma levels of barbital $\mathrm{c}^{14}$ were higher in mice exposed to hypobaric hypoxia during barbital narcosis. These results indicate that hypoxia may reduce the rate of excretion of barbiturates.

13. Mice deprived of social interactions show reduced response to barbiturates with concomitant increase in the rate of metabolism in vivo and in vitro. These findings indicate that deprivation of social stimuli enhances the activity of hepatic microsomal enzymes.

14. Socially deprived mice showed higher concentration of hexobarbital in the body at the time of awakening. Latency to avoidance of electric shock is lower in deprived mice and the decrement in avoidance produced by chlorpromazine is less in the isolated animals. 
These data suggest that socially deprived mice have higher arousal levels with concomitant increase in the threshold of brain neurons to depression.

15. The lowered response to hexobarbital during isolation did not correlate temporally or otherwise with development of aggressiveness. Further, female mice, although exhibiting a reduced response to hexobarbital, did not develop aggressiveness. These findings suggest that alteration in barbiturate sensitivity and development of aggressiveness following social deprivation have different biological bases.

16. Gonadectomy but not adrenalectomy prevented the isolation-induced decrease in response to hexobarbital and development of aggressiveness. This suggests that anabolic steroids may be important in the altered barbiturate sensitivity after isolation. 


\section{REFERENCES}

Agadzhanian, N.A., Bizin, I.P., Doronin, G.P. and Kurznetsov, A.G.: Changes in higher nervous activity and in sorne vegetative functions under prolonged conditions of adinamia and isolation. $2 \mathrm{~h}$. vysshei, nervnai Deiatelnosti, Pavlov (Russian) 13: 953-962, 1963

Aldridge, W.N.: Action of barbiturates upon respiratory enzymes. In Enzymes and Drug Action (CIBA Foundation Symposium), hongar, J., Revek, A., eds.) pp 155-169, Little Brown \& Company, Boston, 1962

Andjus, R.K.: Effect of hypothermia on the kidney. In Physiology of Induced Hypothermia (Dripps, R.D., ed.), pp 226-234, Nat. Acad. Sci. (Pub. \#451), Washington, D.C., 1956

Armstrong, H.G.: Aerospace Medicine, p. 60, Williams and Wilkins Company, Baltimore, 1961

Baumel, I., Robinson, S.M. and Blatt, W.F.: Multi-chamber system for toxicity studies in mice at high altitude. J. Pharm. Sci. 56: 918-919, 1960

Balazs, T., Murphy, J.B. and Grice, H.C.: The influence of environmental changes on the cardiotoxicity of isoprenaline in rats. J. Pharm. Pharmacol. 14, 750-755, 1962

Beach, F.A. and Jaynes, J.: Effects of early experience on the behavior of animals. Psychol. Bull. 51: 239-263, 1954

Bennet, M., Aljure, E.. Narajima, Y. and Pappas, G.: Electronic junctions between teleost spinal neurons, electrophysiology and ultrastructure. Science 141: 262-264, 1963

Bernardini, A.T.: Influence of reduced pressure on administered drugs. Pharmacologist 11: 223, 1969

Bering, E.A., Jr., Effect of body temperature change on cerebral oxygen consumption of the intact monkey. Amer. J. Physiol. 200: 417-422, 1961

Bodansky, $0 .:$ Methemoglobinemia and methemoglobin-producing compounds. Pharmacol. Rev. 2, 144-196, 1951 
Booth, J. and Gillette, J.R.: The effects of anabolic steroids on drug metabolism by microsomal enzymes in rat liver, J. Pharmacol. Exp. Therap. 132, 374-379, 1962

Borzelleca, O.W. and Manthei, R.W.: Factors influencing sleeping time in mice. Arch. Int. Pharmacodyn. Ther. 140: $296-307,1957$

Brain, P.F. and Nowell, N.W.: The effects of isolation as opposed to grouping on adrenal and gonadal function in male and female mice. J. Endocrinol. XVI-XVII, 1969

Brodie, B., Burms, J., Lief, P., Bemste in, E. and Papper, E.: The fate of pentobarbital in man and dog and a method for its estimation in biological naterial. J. Pharmacol. Exp. Therap. 109:26-34, 1953

Brow, J.H.: Physiology of Man in Space. p. 70, Academic Press, New York, 1963

Chance, M.R.A. : Factors influencing the toxicity of sympathomimetic amines to solitary mice. J. Pharmacol. Exp. Therap. 89, 289-296, 1947

Chance, M.R.A.: The contribution of environment to uniformity. Coll. Pap. Lab. Anim. Bur. 6: 59-63, 1957

Chance, M.R.A. and Mackintosh, J.H.: The effects of caging. Coll. Pap. Lab. Anim. Bur. 11: 59-62, 1962

Christian, J.J.: Effect of population size on the adrenal glands and reproductive organs of male mice in populations of mixed size. Amer. J. Physiol. 182: 292-29?, 1955

Cohen, S.I. and Edwards, A.E., The interaction of ISD and sensory deprivation: Physiological considerations. In Recent Advances in Biological Psychiatry, (J. Wurtis, ed.), pp 139-144, Vol. 6, Plenum Press, New York, 1964

Consolo, S., Garattini, S. and Valzelli, I.: Amphetamine toxicity in aggressive mice. J. Pharm. Pharmacol. 17: 53-54, 1965 a

Consolo, S., Garattini, S, and Valzelli, I.: Sensitvity of aggressive mice to centrally acting drugs. J. Pharm. Pharmacol. 17: 594-595, 1965b

Cooper, J.R. and Brodie, B.B.: The enzymatic metabolism of hexobarbital (Evipal). J. Pharmacol: Exp. Therap. 114: 409417,1955 
Darling, R.C. and Roughton, F J.: The effect of methemoglobin in the equilibrium between oxygen and hemoglobin. Amer. J. Physiol. 137: 56-58, 1942

Dennis, W. Causes of retardation among institutional children. J. Genet. Psychol. 96:47-59, 1960

Dennis W. and Dennis, S.J.: Development under controlled environmental conditions. In Readings in Child Psychology (Dennis. W. ed.), pp 104-131, Prentice-Hall, New York, 1951

Dixon, W.J. and Massey, F.J.: Introduction to Statistical Analysis. McGraw-Hill, New York, 1969. 3rd Edition

Dorfman, A. and Goldbaum, I.R.: Detoxification of barbiturates. J. Pharmacol. Exp. Therap. 20:330-337, 1947

Ebert, A.G., Yim, G.K. and Miya, T.S.: Distribution and metabolism of barbital $\mathrm{C}^{14}$ in tolerant and non-tolerant rats. Biochem. Pharmacol. 13, 1267-1274, 1964

Evelyn, R.A. and Malloy, H.T., Microdetermination of oxyhemoglobin, methemoglobin and sulfhemoglobin in a single sample of blood. J. Biol. Chem. 126, 655-662, 1938

Faiman, M.D. and Hable, A.R.: The effect of hyperbaric oxygenation on cerebral amines. Life Sci. 5, 2225-2234, 1966

Field, J.. Fuhrman, F.A. and Martin, A.W.: Effect of temperature on oxygen consumption of brain tissue. J. Neurophysiol. 2. $117-123,1944$

Finley, T.N., Swenson, E.W. and Comroe, J.H. Jr.: The cause of arterial hypoxemia in patients with "alveolar-capillary block symdrome". J. Clin. Invest. 41: 618-625, 1962

Folk, E.G.: Low pressure from terrestrial altitude. In Introduction to Environmental Physiology, pp 213-238, Lea and Febiger, Philadelphia, 1966

Friedman, P.J. and Cooper, J.R.' The role of alcohol dehydrogenase in the metabolism of chloral hydrate. J. Pharmacol. Exp. Therap. 129, 373-376, 1960

Fuhrman, F.A.: The effect of body temperature on the duration of barbiturate anesthesia in mice. Science 105: 387-389, 1947

Gellhorn, E.: oxygen deficiency, carbon dioxide and temperature regulation. Amer. J. Physiol. 120: 190-194, 1937

Giacalone, E., Tansella, M. . Valzelli, I. and Garattini, S.: Brain serotonin metabolism in isolated aggressive mice. Biochem. Pharmacol. 12: 1315-1327, 1968 
Gillette, J.R., Brodie, B.B. and LaDu, B.N.I The oxidation of drugs by liver microsomes: on the role of TPNH and oxygen. J. Pharmacol. Exp. Therap. 119: 532-539, 1957

Goldbaum, L.R. and Smith, P.K. T The interaction of barbiturates with serum albumin and its possible relation to their disposition and pharmacologic actions. J. Pharmacol. Exp. Therap. 111: 197-210, 1954

Goldfarb, W.: Emotional and intellectual consequences of psychologic deprivation in infancy: A re-evaluation. In Psychopathology of Childhood (Hoch, P.H. and Zubin, J. ed.) pp 105-119, Grune and Stratton, New York, 1955

Guarino, A.M., Rosecrans, J.A., Mendillo, A.B. and DeFeo, J.J.: Brain levels of norepinephrine and serotonin in isolated rats receiving pargyline. Biochem. Pharmacol. 16: $227-228,1967$

Gurdjian, E.S., Webster, J.E. and Stone, W.E.: Cerebral constituents in relation to blood gases. Amer. J. Physiol. 156: $149-157,1949$

Guyton, A.C.: Aviation, high altitude and space physiology. In Textbook of Medical Physiology, pp 621-636, W.B. Saunders Co., New York, 1969, 3rd Edition

Haley, T, and McCormick, W.: Pharmacological effects produced by intracerebral injection of drugs in the conscious mouse. Brit. J. Pharmacol. 12, 12-15, 1957

Hardy, J.D.: Physiology of temperature regulation. Physiol. Rev. 41: $521-541,1961$

Hatch, A., Balazs, T., Wiberg, G.S, and Grice, H.C., Longterm isolation stress in rats. Science 142: 507-512, 1963

Heller, H., Herdan, G. and Zaidi, S.M.: Seasonal variations in the response of rats to the antidiuretic hormone. Brit. J. Pharmacol. Chemotherap. 12, 100-105, 1957

Henderson, $Y_{\text {. }}$ and Radloff, E.: The chemical control of breathing, as shown in the acid-base balance of the blood, under progressive decrease of oxygen. Amer. J. Physiol. 101: $647-661,1932$

Heron, W., Cognitive and physiological effects of perceptual isolation. In Sensory Deprivation (Solen, P. et al, ed.) pp 6-33. Harvard University Press, Cambridge, 1961

Huennekens, F., Caffrey, R., Bosford, R, and Gabrio, B.W.: Erythrocyte metabolism IV. Isolation and properties of methemoglobin reductase. J. Biol. Chem. 227: 261-270, 1957 
Hurder, W.P.: Changes in maze performance in rats following exposure to anoxia. J. Comp. Physiol. Psychol. 44: $473-478,1951$

Jaffe, E.R.: Metabolic processes involved in the formation and reduction of methemoglobin in human erythrocytes. In The Red Blood Cell (Bishop, C., Sugenor, D.M., ed.) pp 397422. Academic Press, New York, 1964

Jouvet, M.: Biogenic amines and the states of sleep. Science 153: $32-41,1969$

Kalser, S.C., Kelvington, E.J., Kunic, R, and Randolph, M.: Drug metabolism in hypothermia. Uptake, metabolism and excretion of $\mathrm{C}^{14}$ procaine by the isolated, perfused rat liver. J. Pharmacol. Exp. Therap. 164: 396-404, 1968

Killam, K.F. and Bain, J.A.: Convulsant hydrazides I: In vitro and in vivo inhibition of vitamin B6 enzymes by convulsant hydrazides. J. Pharmacol. Exp. Therap. 119: 255262,1957

Kimbrell, G.M.: A preliminary analysis of the agnostic behavior patterns shown by three strains of mice, Mus musculus, in the foot shock situation. Ph.D. dissertation, Dept. Psychology, University of Tennessee, 1957

King, J.J., Chiun, G., Pum Lee, Y. and Visscher, M.B.: Single versus multiple occupancy and convulsion frequency in $\mathrm{C}_{3} \mathrm{H}$ mice. Proc. Soc. Exp. Biol. (N.Y.) 88: 661-663, 1955

King, J.A. and Connon, H.: Effects of social relationships upon mortality in $\mathrm{C}_{57} \mathrm{BL} / 10 \mathrm{mice}$. J. Comp. Physiol. Psychol. 47. $326-330,1954$

Kottke, J., Phalen, J.S., Taylor, C.B., Visscher, M.B. and Evans, G.T.: Effect of hypoxia upon temperature regulation of mice, dogs and man. Amer. J. Physiol. 153: 10-15, 1948

Lamar, C. Jr. and Sellinger, 0.Z.: The inhibition in vivo of cerebral glutamine synthetase and glutamine transferase by the convulsant methionine sulfoximine. Biochem. Pharmacol. 14: 489-506, 1965

Lawes, T.G.I Schizophrenia, Semyl and sensory deprivation. Brit. J. Psych. 109: 243-250, 1963

Leadbeater, I. and Davies, D.B.: The stability of the metabolizing enzymes of liver microsomal preparations. Biochem. Pharmacol. 13: 1607-1617, 1964

Ledwith, F.: The effects of hypoxia on shuttle avoidance in the rat. Psychon. Sci. 8: 203-204, 1967 
Lehman, A.S, and Hanzlick, P.J., Emetic and fatal doses of digitalis at high altitudes. Proc. Soc. Exp. Biol. (N.Y.) 30 , $140-143,1932$

Leiderman, P.H. and Stern, R.: Selected bibliography of sensory deprivation and related subjects. Tech. Rept. ASD 61-259 (Contract \#AF33, 616-6110) Wright Patterson AFB, Ohio, July, 1961

Lilly, J.: Mental effects of reduction of ordinary levels of physiologic stimuli on intact healthy persons. Fsych. Res. Rep. 5: 1-9, 1956

Malmo, R.B. and Finnan, J.L.: A comparative study of eight tests in the decompression chamber. Amer. J. Physiol. 57: $389-405,1944$

Moyer, J.H., Morris, G.C. and DeBakey, M.E.: Effect of hypothermia on the kidney, In Physiology of Induced Hypothermia (Dripps, R.D. ed.) Nat. Acad. Sci. (Pub. \#451) Washington, D.C., pp 226-234, 1956

Maynert, E.W. and Van Dyke, H.B., The absence of localization of barbital in divisions of the CNS. J. Pharmacol. Exp. Therap. 28, 184-187, 1950

McFarland, R.A.l The effects of oxygen deprivation (high altitude) on the human organism. Report 13, U.S. Dept. Commerce, Bureau of Air Commerce, 1938

McFarland, R.A. and Halperin, M.H.: The relation between fovial visual acuity and illumination under reduced oxygen tension. J. Gen. Physiol. 23: 613-630, 1940

Melzuck, R., Effects of early restriction on adult behavior. Paper read at the Amer. Psychopathol. Assoc., 1963

Monge, C.l Aclimatacion en los Andes. Lima, Facultad de Medicina, 1960

Moore, A.W. and Ward, J.C.: The effect of altitude on the action of drugs I. Strychnine. J. Amer. Pharm. Assoc. (Sci. ed.) $24: 460-469,1935$

Murphy, C.W., Kurlents, E., Kleghorn, R.A. and Hebb, D.0.: Absence of increased corticoid excretion with the stress of perceptual deprivation. Canad. J. Biochem. Physiol. 33: $1062-1063,1955$

Mustala, 0, and Azarnoff, D.L.: Effect of oxygen tension on drug levels and pharmacologic action in the intact animal. Proc. Soc. Exp. Biol. (N.Y.) 132, 37-41, 1969 
Myers, T.F., Murphy, D.B., Smith, S. and Goffard, S.J.: Experimental studies of sensory deprivation and social isolation. Hum RRO Tech. Rept., pp 66-68, George Hashington University, June, 1966

Nair, V., Brown, T., Bau, D, and Siegel, S. . Hypothalamic regulation of hepatic hexobarbital metabolizing enzyme system. Europ. J. Pharmacol. 91: 31-40, 1970

Novick, W.J. Jr., Stoler, C.M. and Swagzdig, J.: The influence of steroids on drug metabolism in the mouse. J. Pharmacol. Exp. Therap. 151: 139-142, 1966

Oja, S., Oja, H. and Saraja, H.: Cerebral free amino acids in rats undergoing varying periods of anesthesia and hypothermia. Ann. Acad. Sci. Fenn. 142: 3-14, 1968

Oswald, N, and Fry, J.: Diseases of the Respiratory system, F.A. Davis Co., Philadelphia, 1962

Roberts, E, and Frankel, S.: Further studies of glutamic acid decarboxylase in brain. J. Biol. Chem. 190, 505-512, 1951

Robinson, S.M., Baumel, I. and Blatt, W.F.: The effect of simulated altitude exposure on the lethality of sympathomimetic amines. Toxicol. Appl. Pharmacol. 15, 304-309, 1969

Robinson, S.M., Blatt. W.F., Schatz, R, and Joy, R.: The effects of simulated altitude and aggregation on hexobarbital sleeping time in mice. Fed. Proc. 27:282, 1968

Sass, M.D., Caruso, C.J. and Axelrod, D.R. : Accumulation of methylene blue by metabolizing erythrocytes. J. Lab. clin. Med. 69, 447-455, 1967

Schade, J.P. and McMenemey, W.H. (ed.): Selective Vulnerability of the Brain in Hypoxaemia, Davis Co., Philadelphia, 1963

Schaeffer, K.E.: Environmental Effects on Consciousness. The . Macmillan Co, N.Y.

Setnikar, J. and Temelcou, 0.: Effect of temperature on toxicity and distribution of pentobarbital and barbital in rats and dogs. J. Pharmacol. Exp. Therap. 135: 213-222, 1962

Shock, N.W. and Scow, R.0., The effect on learning of repeated exposure to lowered oxygen tension in the inspired air. J. Comp. Physiol. Psychol. 24: 55-63, 1942

Sigg, E.B., Day, C.A. and Colombo, C.: Endocrine factors in isolation-induced aggressiveness in rodents. Endocrinology 28, $679-684,1966$ 
Sparvieri, F. Effeti della depressione barometrica e di aleuna farmaci tranquillanti sulla attivita motorica spontanea del topino. Riv. Med. Aero 23: 397-402, 1960

Spitz, R.A.: Anaclitic depression. Psychoanalytic Study of the Child 2: 313-342, 1946

Tainter, M.L.: Low oxygen tension and temperature on the actions and toxicity of dinitrophenol. J. Pharmacol. Exp. Therap. 51, 45-58, 1934

Thompson, R.: The comparative effects of ECS and anoxia on memory. J. Comp. Physiol. Psychol. 50: 397-400, 195?

Valzelli, I. and Garattini, S.: Behavioral changes and serotonin turnover in animals. Adv. Pharmacol. 6B: 249-260, 1969

Vanderbilt, J.M., Pfeiffer, C.P., Kaiser, Mo and Silbert, M.: Methemoglobinemia after administration of p-aminoacetophenon and p-aminopropiophenone. J. Pharmacol. Exp. Therap. 80: 3138,1944

Van Liere, E.J. and Stickney, J.C.: Hypoxia, University of Chicago Press, Chicago, 1963

Wenzel, D.G. and Lal, H.: The relative reliability of the escape reaction and righting reflex sleeping times in the mouse. J. Amer. Pharm. Assoc. (Sci. ed.) 48, 90-91, 1959

Weinstein, S.A.: The effect of hypoxia on leamed escape from carbon dioxide. Psychon. Sci. 6: 91-92, 1966

Weisman, A. and Koe, K.B.: m-Fluorotyrosine convulsions and mortality: Relationship to catecholamine and citrate metabolism. J. Pharmacol. Exp. Therap. 155: 135-144, 1967

Wiberg, G.S. and Grice, H.C.: Effect of prolonged caging on toxicity parameters in rats. Fd. Cosmet. Toxicol. 3: 597603,1965

Wood, J.D.: A possible role for GABA in the homeostatic control of brain metabolism under conditions of hypoxia. Exp. Brain Res. 4: 81-84, 1967

Wood, J.D., Watson, W.J. and Ducker, A.J.: Oxygen poisoning in various mammalian species and the possible role of GSBA metabolism. J. Neurochem. 14: 1067-1074, 1967

Wood, J.D., Watson, W.J. and Ducker, A.J.I The effect of hypoxia on brain GABA levels. J. Neurochem. 15: 603-608, 1968 
Yen, C.Y., Stanger, R.I. and Millman, N.: Ataractic suppression of isolation-induced aggression behavior. Arch. Int. Pharmacodyn. 123, 179-185, 1959

Zubek, J.P. and Schutte, W.: Urinary excretion of adrenaline and noradrenaline during prolonged perceptual deprivation. J. Abnorm. Psychol. 21: 328-334, 1966 
VITA

Irwin Paul Baumel was born on December 10, 1941 on New York City, where he obtained his elementary and high school education. Mr. Baumel enrolled at Columbia University in 1959 and received the Bachelor of Science degree in pharmacy in June, 1963. Mr. Baumel was employed as a registered pharmacist from 1963-1965. He entered the Graduate School at Northeastern University, Boston, in September, 1965, where Mr. Baumel completed the requirements for the Master of Science degree in pharmacology in June, 1967. Mr. Baumel entered the Graduate School of the University of Rhode Island in September, 1967 and completed the requirements for the Doctor of Philosophy degree in pharmacology in July, 1970. He is a member of the American Association for the Advancement of Science, Rho $\mathrm{Chi}$ and Sigma Xi.

Mr. Baumel is married to the former Susan Brenda Lehrer of New York City. They celebrated the birth of their daughter, Marcy Lymn, on January 29, 1970.

Mr. Baumel has accepted a position as research associate in the department of neurology at the Yale University School of Medicine, New Haven, Connecticut. 


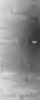

